\title{
Survey of appropriate skills required by forensic accountants: empirical evidence from a developing economy
}

\author{
Madan Lal Bhasin \\ Professor of Accounting, Bang College of Business, KIMEP University, Almaty \\ E-mail:madan.bhasin@rediffmail.com
}

\begin{abstract}
Accounting frauds and scams are perennial. They occurred in all eras and in all countries, and affected many organizations, regardless of their size, location, or industry. From Enron and WorldCom in 2001 to Madoff and Satyam in 2009, accounting frauds and scams have been dominating news items in the past decade. Corporations and regulatory bodies are trying their best to analyze and correct existing defects in their reporting system. After having an overview of the fraud scenario in India, it is apparent that criminals have become technology-savvy, and invented newer schemes to perpetuate crimes. In the current reporting environment of "digital-age," forensic accountants (FA's) are in great demand for their 'niche' accounting, auditing, legal and investigative skills. Hence, 'forensic' accounting has been thrown in the "forefront of the crusade" against financial deception and accounting scandals.

The present study investigates through a questionnaire, which was conducted in three leading States of the national capital region (NCR) of India during 2011-12, "if there are differences in the views of the relevant skills of FA's among accounting practitioners, academics, and users of forensic accounting services." From the statistical test of the hypotheses propounded for this study, we discovered that "core skills are not enough requirements for FA's, there are significant differences in the relevant skills of FA's, as given by previous researchers with the current research, and the necessary skills of FA's, as identified by both academics and professionals, will hopefully meet employers' expectations too." Therefore, FA's, being professional experts having 'sixth' sense and possessing 'special' skills are urgently required to counter all the ingenuity of these criminals. At present, some Universities in India are considering adding forensic accounting course to their curriculum. The results of this study may provide some guidance to educators for the development of forensic accounting curriculum by identifying the pertinent skills to accompany such a program of study.
\end{abstract}

Keywords: Accounting frauds, scams, forensic accounting and forensic accountants, skills required, academics, practitioners, users of services, corporate governance.

\section{Introduction}

Accounting scandals and frauds are perennial. Innumerable instances of scandals and frauds have plagued our society since before the "Industrial Revolution." They occurred in all eras and in all countries. During the last few decades, there have been numerous financial frauds and scandals, which were milestones with historical significance. Enron, WorldCom and Parmalat are just few examples of the well-known accounting scandals and/or frauds. However, what is not so well-known is that almost every country had its own accounting scandals and frauds. The media has fortunately reported scandals and bankruptcies in companies, from time to time, both from the 'developed' and 'developing' countries. Some of them are listed here to give examples. HIH Insurance, Harris Scarfe and One.Tel (Australia), Global Crossing (Bermuda), Nortel Networks (Canada), Zhengzhou Baiwen, Shandong Bohai, Jinzhou Port, Kelon (China), Vivendi Universal (France), ComRoad, Phenomedia, MLP, Hugo Boss, Nici, Zapf Creation (Germany), Dynamic Life, Ipirotiki Software (Greece), Parmalat, Freedomland, Finmatica (Italy), Elan (Ireland), JVG Group of companies, UTI, Global Trust Bank, Citibank, Wipro, Satyam (India), IHI, Sanyo Electric (Japan), Baan Company, Ahold NV, LCI Computer, Landis (Netherlands), Gescartera, Bafisa, Afinsa and Forum Filatelico (Spain), ABB, Skandia, Prosolvia (Sweden), Adecco International (Switzerland), Barings Bank Equitable Life, Wiggins, Versailles (UK), and Adelphia Communication, IBM, Enron, Xerox, Madoff Securities, Lehman Brothers (U.S.). In addition, some of the Asian countries have also experienced similar fraud/scam cases, such as, PT Bank Bali, Sinar Mas Group (Indonesia), Bangkok Bank of Commerce (Thailand), United Engineers Bhd (Malaysia), Samsung Electronics, Hyundai (Korea). Surprisingly, this list is rapidly growing every year. The corporate collapses of recent times, culminating with massive 
collapses has suggested that "there are major systemic problems facing the way in which corporations and corporate governance (henceforth, CG) systems operate" [11, pp. 16-42].

Indeed, fraud is a world-wide phenomenon that affects all continents and all sectors of the economy, and most organizations may face regardless of their size, industry or country. If the organization has valuable properties (like cash, goods, information, or services), then fraud may be attempted. It is often "high-profile frauds in large multinational organizations that are reported on in the media and the smaller organizations may feel they are unlikely to be a target of fraudsters." Periodically, the latest major fraud hits the 'headlines' as other organizations sit-back and watch, telling them that "it could not happen here!" But the reality is that fraud can happen anywhere and anytime. While only relatively few major frauds are picked up by the media, huge sums are lost by all kinds of businesses as a result of the high number of smaller frauds that are committed.

The term 'fraud' essentially "involves using deception to dishonestly make a personal gain for oneself and/or create a loss for another." Although the legal definitions of fraud may vary from country to country, most are based around these general themes. Examples of fraud commonly include activities, such as, theft, corruption, conspiracy, embezzlement, money-laundering, bribery and extortion. This paper focuses on fraud against businesses and corporate-sectors, typically by those "internal to the organization". According to the Association of Certified Fraud Examiners [6], "there are three main categories of fraud that affect organizations: asset misappropriations, fraudulent financial statements, and corruption. Surveys in the past have shown that "asset misappropriation is the most widely reported type of fraud in India, although corruption and bribery are growing the most rapidly." The risks of fraud may only be increasing, as we see growing globalization, more competitive markets, rapid developments in technology, and periods of economic difficulty.

There have been many attempts to measure "the true extent of fraud, but compiling 'reliable' statistics around fraud is not easy." As one of the key aspects of fraud is 'deception', it can be difficult to identify and survey results often only reflect the instances of fraud that have actually been 'discovered'. It is estimated that "the majority of frauds go undetected and, even when a fraud has been found it may not be 'reported'. One reason for this may be that a company that has been a 'victim' of fraud does not want to risk 'negative' publicity." Although survey results and research may not give a complete picture, the various statistics do offer a useful indication as to the extent of the problem. Findings vary, and it is difficult to obtain a complete picture as to the full extent of the issue, but these surveys all indicate that fraud is prevalent within organizations and remains a serious and costly problem. According to a study of organizations world-wide, 30 percent of companies were victims of an economic crime (or fraud) in the last year [50 pp. 601-18]. From Enron to WorldCom in 2001, and Madoff to Satyam in 2009, it appears that corporate accounting fraud is a major problem that is increasing, both in its frequency and severity. According to the Association of Certified Fraud Examiners' [6] 'Report to the Nations,' "the cost of fraud to the U.S. organizations is extensive -5 percent of annual revenues, despite increased emphasis on anti-fraud controls and recent legislation to combat fraud." Indeed, the ACFE survey found that "whistle-blowing is the single most common method of fraud detection" [64, pp.213-27]. Although it is generally accepted that the Sarbanes-Oxley (SOX) Act of 2002 has improved 'corporate governance' (CG) and decreased the incidence of fraud, recent studies and surveys indicate that investors and management continue to have concerns about financial statement fraud as summarized in Table 1.

No doubt, economic crime and fraud remains an intractable problem for companies globally and India is no exception. As India Inc. goes global, economic crime is emerging as a bigger threat than before. When companies in India expand their reach to other countries, they are exposed to not just 'home-grown' frauds, but also frauds prevalent in other markets. In fact, economic crime continues to be an expensive proposition for companies, both in terms of losses due to such crimes and the cost of managing frauds. According to PwC [60], 'The 4th Biennial Global Economic Crime Survey: India,' "Companies in India suffered average direct losses of US \$ 1.5 million (INR 6 crores) due to fraud in the preceding two years. More importantly, the cost of managing fraud-that includes legal costs, the cost of investigating frauds, stakeholder management and public relation costs-is also very high. Respondents in India reported average management costs of US \$1 million (INR 4 crores)-almost twice that of the global and Asia \& Pacific region's average of US \$0.55 Million (INR 2.2 crores) and US \$ 0.41 Million (INR 1.6 crores), respectively, which is in addition to direct loss caused by fraud" (see Table 2). It is important to note that the reported averages do not include the opportunity loss suffered due to counterfeit products. Nor do they consider ill-gotten revenues associated with sales contracts procured through payment of a bribe. However, damage from intangible factors such as damage to reputation or brand, decline of staff morale and impaired business relations cannot be underestimated as these elements can be undermined by the occurrence or even perception of fraud. To conclude, "Companies in India are more exposed to fraud losses and costs than their global counterparts." 
Table 1: Magnitude of losses suffered due to frauds-a global scenario

Reporting Authority

The ACFE "Report to the
Nations on Occupational Fraud
and Abuse" (2010)

The COSO Fraud Report (2010)

The KPMG Survey (2009)

Deloitte Forensic Center
Webcast

National Fraud Authority (U.K.), Annual Fraud Indicator (2012)

The Ernst \& Young's "India Fraud Indicator report” (2012)

The Association of Certified Fraud Examiners' (ACFE) found that financial statement fraud, while representing
less than 5 percent of the cases of fraud in its report, was by far the most costly, with a median loss of $\$ 1.7$
million per incident. Survey participants estimated that the typical organization loses 5 percent of its revenues to
fraud each year. Applied to the 2011 Gross World Product, this figure translates to a potential projected annual
fraud loss of more than $\$ 3.5$ trillion. The median loss caused by the occupational fraud cases in our study was
$\$ 140,000$. More than one-fifth of these cases caused losses of at least $\$ 1$ million. The frauds reported to us lasted
a median of 18 months before being detected.
a median of 18 months before being detected.

The Committee of Sponsoring Organizations of the Treadway Commission analyzed 347 frauds investigated by the U.S. Securities and Exchange Commission (SEC) from 1998 to 2007 and found that the median dollar amount of each instance of fraud had increased three-times from the level in a similar 1999 study, from a median of $\$ 4.1$ million in the 1999 study to $\$ 12$ million. In addition, the median-size of the company involved in fraudulent financial reporting increased approximately six-fold, from $\$ 16$ million to $\$ 93$ million in total assets, and from $\$ 13$ million to $\$ 72$ million in revenues.

A Survey of 204 executives of U.S. companies with annual revenues of $\$ 250$ million or more found that 65 percent of the respondents considered fraud to be a significant risk to their organizations in the next year, and more than one-third of those identified financial reporting fraud as one of the highest risks.

Fifty-six percent of the approximately 2,100 business professionals surveyed in a webcast about reducing fraud risk predicted that more financial statement fraud would be uncovered in 2010 and 2011, as compared to the previous three years. Almost half of those surveyed (46 percent) pointed to the recession as the reason for this increase.

The scale of fraud losses in 2012, against all victims in the U.K., is in the region of $£ 73$ billion per annum. In 2006, 2010 and 2011, it was £13, 30 and 38 billion, respectively. The 2012 estimate is significantly greater than the previous figures because it includes new and improved estimates in a number of areas, in particular against the private sector. Fraud harms all areas of the UK economy.

The losses suffered due to fraud amount to INR 66 billion. Delhi witnessed the largest number of fraud cases and suffered the highest aggregate losses by fraud (as compared to the rest of the country) in 2011-12. The financialservices sector was the worst hit, with more than 63 percent of the total fraud cases reported in 2011-12, followed by technology and transportation. In the financial-services sector, banking was the major victim with 84 percent of the total number of reported fraud cases. According to the data compiled by the Reserve Bank of India (RBI), the money lost by banks due to scams and fraud has doubled in the past four years. Losses incurred by banks due to fraud increased by 88 percent in 2010-11 to exceed INR 37.9 billion (more than INR 20.1 billion in 2009-10).

\begin{tabular}{|c|c|c|c|}
\hline Items of Loss & India & Asia \& Pacific & Global \\
\hline 1. Direct loss (average in US\$) + & $1,535,217$ & $1,438,526$ & $2,420,700$ \\
\hline 2. Management cost (average in US\$) + & $1,029,184$ & 416,393 & 550,355 \\
\hline 3. Damage to reputation or brand (\% of cases) + & 92 & 89 & 88 \\
\hline 4. Decline in staff morale ( $\%$ of cases $)+$ & 88 & 92 & 88 \\
\hline 5. Damage to external business relations $(\%$ of cases $)+$ & 84 & 87 & 84 \\
\hline 6. Strained relations with regulator ( $\%$ of cases) & 75 & 83 & 80 \\
\hline
\end{tabular}

Unfortunately, the corporate collapses of recent times have suggested that there are major 'systemic' problems facing the way in which corporations and CG systems operate across the globe. On a number of occasions, over the past few decades, major public companies have experienced financial reporting frauds, resulting in sudden turmoil in the US capital markets, a loss of shareholder value, and, in some cases, the bankruptcy of the company itself. During the recent series of corporate fraudulent financial reporting incidents in the US, "almost all cases of foreign corporate accounting frauds were committed by the entities that conducted their businesses in more than one country, and most of these entities are also listed on U.S. stock exchanges." The corporate scandals of the last few years came "as a shock not just because of the enormity of failures, but also because of the discovery that questionable accounting practice was far more insidious and widespread than previously envisioned" [12, pp. 79-105]. No doubt, fraudulent financial reporting can have significant consequences for the 'organization' and its 'stakeholders,' as well as, for 'public-confidence' in capital markets. For instance, according to COSO Report [25], "Periodic high-profile cases of fraudulent financial reporting raise concerns about the credibility of the US financial reporting process and call into question the roles of management, auditors, regulators, and analysts, among others."

The wave of financial scandals at the turn of the 21 st century elevated the awareness of fraud and the auditor's responsibilities for detecting it. Unfortunately, the frequency of financial statement fraud has not seemed to decline since the passage of the Sarbanes-Oxley Act in July 2002 [43, pp. 231-52]. The high-incidence of fraud is "a serious concern for investors as fraudulent financial reports can have a substantial negative impact on a company's existence, as well as, the market value." For instance, the lost market capitalization of 30 high-profile financial scandals caused by fraud from 1997 to 2004 is more than $\$ 900$ billion, which represents a loss of 77 percent of market value for these 
firms, while recognizing that the initial market values were likely inflated as a result of the financial statement fraud. Despite intense efforts to stamp out corruption, misappropriation of assets, and fraudulent financial reporting, it appears that fraud in its various forms is a problem that is increasing in frequency and severity.

Financial statement fraud was a contributing factor to the recent financial crisis and it threatened the efficiency, liquidity and safety of both debt and capital markets [15]. Furthermore, it has very significantly increased 'uncertainty' and 'volatility' in financial markets, shaking 'investor' confidence worldwide. It also reduces the creditability of financial information that investors use in their investment decisions [68, pp. 176-205]. When taking into account the loss of investor confidence, as well as, reputational damage and potential fines and criminal actions, it is clear why financial misstatements should be every manager's worst fraud-related nightmare [34]. From time-to-time, corporations and regulatory bodies have tried to analyze and correct any existing defects, if any, in their reporting systems. In addition, discussion on the relevance of "forensic accounting" in detecting accounting scandals has emerged in recent years. All these cases imply that the corporations have failed to supply accurate information to their investors, and to provide appropriate disclosures of any transactions that would impact their financial position and operating results. The recent accounting scandals have induced a crisis of confidence in financial reporting practice and effectiveness of CG mechanisms [56, pp. 52-67]. No doubt, recent corporate accounting scandals and the resultant outcry for transparency and honesty in reporting have given rise to two disparate yet logical outcomes. First, forensic accounting skills have become crucial in untangling the complicated accounting maneuvers that have obfuscated financial statements. Second, public demand for change and subsequent regulatory action has transformed CG scenario [9, pp. 1000-1010]. Therefore, more and more company officers and directors are under ethical and legal scrutiny. In fact, both these trends have the common goal of addressing the investors' concerns about the transparent financial reporting system. However, the failure of the corporate communication structure has made the financial community realize that there is a great need for skilled professionals that can identify, expose, and prevent structural weaknesses in three key areas: poor corporate governance (CG), flawed internal controls, and fraudulent financial statements. Forensic accounting skills, therefore, are becoming increasingly relied upon within a corporate reporting system that emphasizes its accountability and responsibility to stakeholders.

In general, it can be claimed that the above accounting scandal occurred because of integrated factors, such as, lack of auditor independence, weak law-enforcement, dishonest management, poor internal-control and inability of CG mechanisms in monitoring top-management behaviors. The SOX 2002 imposes potentially serious penalties on firm executives with fines of up to $\$ 5$ million and/or imprisonment up to 20 years. At the same time, this legislation requires that these firms tighten their internal controls over financial reporting [7, pp. 1-21]. Unfortunately, it is also true that most frauds are perpetrated by people in positions of trust in the accounting, finance, and IT functions (20, pp.1-21). Consequently, there should be alternative tools to detect the possibility of financial frauds. Forensic accounting can be seen as one of such tools. An understanding of effective fraud and forensic accounting techniques can assist forensic accountants (henceforth, FA's) in identifying illegal activity and discovering and preserving evidence. For instance, some regulators have apparently noticed the need for forensic accounting [22]. For example, the Sarbanes-Oxley Act (SOX), the Statement on Auditing Standards-99 (SAS 99), and the Public Company Accounting Oversight Board (PCAOB) have not removed the pressures on CFOs to manipulate accounting statements. The PCAOB recommends that "an auditor should perform, at least, one walk-through for each major class of transactions." However, SAS 99 does not require the use of forensic specialists but does recommend brainstorming, increased professional skepticism, and unpredictable audit tests. The PCAOB has raised concerns about auditors' fraud judgments and the quality of their brainstorming sessions $[21,16]$.

The Institute of Chartered Accountants of India (ICAI) has taken the challenge of training some Chartered Accountants to become Certified Forensic Accountants (CFAs). It is providing a "Certificate Course on Forensic Accounting and Fraud Detection using IT and CAATs," with 100 hours spread over 6 weekends. This challenge is yet to be embraced by most of the Indian Universities providing higher education. At present, very few academic institutions are offering a full course on forensic accounting, either at undergraduate or graduate level, despite the high need for this category of professionals. For example, India Forensic (Pune) is one of the few, which conducts a Certificate course in Bank Forensic Accounting (CBFA), Certified Anti Money Laundering Expert (CAME), and Certified Forensic Accounting Professional (CFAP). The Institute of Chartered Financial Analysts of India University (Tripura) also offers a "Postgraduate Diploma in Forensic Accounting." However, some colleges/universities are providing "Forensic Science" courses in India. Most probably, this is on account of lack of information about universally accepted skill-mix of FA's. Both academics and professionals should agree on the required skill-mix of FA's, which could be embedded in their course structure. This scenario highlights a gap between forensic accounting practice and education in the country. As academic institutions contemplate the addition of fraud and forensic accounting into their curricula, there is a need for an in-depth examination of the knowledge, skills and abilities necessary for individuals to function in these fields. In spite of the fact that forensic accounting is offered by some professional accountancy bodies and Universities in the United States, Canada, United Kingdom etc., controversies are still looming the academic environment on the best skills needed for this crucial function. The international academic community has tried to address the question: who are the right people to suggest forensic accounting skills? 
This paper is organized as follows. Section 2 briefly summarizes the creative and fraudulent accounting practices followed by some of the Indian companies. In the current reporting environment, FA's are in great demand for their accounting, auditing, legal, and investigative skills. Therefore, section 3 highlights the need for forensic accounting and the skills required on the part of FA's. The review of literature that motivates this study is performed in section 4. Section 5 discusses the methodology and procedures used in gathering and analyzing the survey data for the study. Section 6 presents the results and discussion of the implications of the study. Last section summarizes the conclusion

\section{Fraudulent and creative accounting practices used by the Indian companies}

Fraudulent financial reporting, no doubt, can have significant consequences for the organization and its stakeholders, as well as for public confidence in the capital markets. Periodic high-profile cases of fraudulent and creative financial reporting in India have raised concerns about "the credibility of the financial reporting process and called into question the roles of management, auditors, regulators, and analysts, among others." India has been amongst the fastest growing economies in the world in the last decade. In spite of global economic slowdown, the Indian economy grew by 8 per cent in 2010-11 and is estimated to grow by 7 per cent in 2011-12. There is significant foreign investor interest as shown by a 50 per cent increase in FDI this year. Fortunately, it has remained relatively unaffected by the global economic crisis, thanks to strong fundamentals of the economic policy. However, despite this situation "the confidence of international investors and domestic entrepreneurs has been low in the last two years, thanks to the various scams and frauds that have come to light during this period."

The frauds in the 'Indian financial markets' have been known for many years. According to CapitalVia Global Research Ltd. (www.capitalvia.com), "The following are examples of some of the popular Indian Financial Market Scams (losses suffered): 1992 Harshad Mehta Securities Scam (Rs. 5,000 crores), 1995 Bhansali Scam (Rs. 1,200 crores), 2001 Ketan Parekh Scam (Rs. 1250 crores), 2001 The UTI Scam (Rs. 4,800 crores), 2008 Satyam Scam (Rs. 10,000 crores), 2008 The 2-G Spectrum Swindle (Rs. 60,000 crores), 2009 Madhu Koda Scam (Rs. 4,000 crores), etc. etc. Fruad committed by the Satyam Computer Services Ltd. has been labeled by the media as "India's Enron." Some other popular scams were: Indian Coal Allocation Scam, Commonwealth Games Scam, Bofors Scam, Fodder Scam, Hawala Scam, The IPL Scam, Adarsh Housing Society Scam, Barak Missile Scam, Kargil Coffin Scam, Mining Scam, Telgi Scam and so on. The list of scams in India is never ending and unfortunately growing very fast, every year.

The need for improving "CG and ethical culture across public and private sector companies has never been felt as acutely as is being felt now." This resounding sentiment is echoed in the 'KPMG India Fraud Survey [46]' as: "The last few years have seen increased number of frauds reported in India, as well as, globally. From Satyam, Adidas-Reebok, Common Wealth Games and OnMobile in India to LIBOR manipulation, securities trading, over-riding international sanctions on the global front, we have seen some of the more sophisticated and large frauds coming to light." With reports indicating that as much as 5 percent of annual revenues could be lost due to frauds [6], organizations today are required to be more cognizant of the damages that frauds can do. Despite the serious risks that fraud presents to business, "many organizations still do not have 'formal' systems and procedures in place to prevent, detect and respond to fraud. While no system is completely foolproof, there are steps which can be taken to deter fraud and make it much less attractive to commit." All businesses are confronted with the risk of fraud. How they respond-the nature of their approach to prevention, detection, investigation and disclosure-will separate those who manage through the issues from those who suffer significant losses.

In addition, cybercrime incidents are on the rise across the world and India is no exception to this trend. As per Norton's Cybercrime Report [55], "cybercrime cost the global economy (in both direct damage and lost productivity time) USD 388 billion in 2011. India is estimated to have damages of USD 7.6 billion (INR 341 billion) due to cybercrime in 2011. The high cost of cybercrime is a direct result of the number of people defrauded by it." Another major concern with cybercrime is its low detection level and negligible prosecution. The monetary loss due to information theft is impossible to assess as it depends upon the nature of information stolen. However, such losses can neither be recovered through insurance coverage nor is the law able to protect from such incidents. However, Norton's Cybercrime Report mentions that close to 30 million people were affected by cybercrime in 2011 in India as against 431 million globally. National Crime Records Bureau [54] states, "India has seen an increase in the number of cybercrime cases filed. In 2011, a total of 1,791 and 422 cybercrime cases were registered under the Information Technology Act, 2000 and the Indian Penal Code respectively, as opposed to 217 and 328 in 2007." Similarly, according to Havoscope Global Black Market Index [39], "Intellectual property fraud, counterfeiting and piracy are rampant in India and no industry has been spared. Counterfeit and pirated goods in India are estimated to be worth over USD 5 billion. The global value of counterfeit and pirated goods, currently at $\$ 650$ billion, is likely to more than double by 2015." Moreover, Transparency International's 'Global Corruption Report [39]' states, “The everyday face of corruption-bribes, kickbacks, tax avoidance, selling influence-is well-known and has distorted economies, demoralized publics and torn asunder the moral fabric of many a society." While there is greater awareness of fraud and misconduct among corporate-sector of 
India, the associated risks need to be considered at a 'strategic' level. Investments need to be prioritized to build a sustainable ecosystem that can mitigate frauds efficiently, including frauds of the future. The KPMG India Fraud Survey [46] has highlighted the emergence of newer forms of fraud and reliance on technology to perpetrate them. Cybercrime, intellectual property (IP) fraud, piracy and counterfeiting, and identity theft have been identified as the key fraud risks of the future. However, in order to maintain this robust economic growth, we need an environment free from major risks. With terrorism going digital, we are at the threshold of 'new' emerging risks. It is, thus, imperative for all the stakeholders, the corporate sector, government and civil society, to understand, analyze and address these risks.

India is a 'developing' economy where corporate-sector is contributing a major part in national income. Most of the Indian corporations are spreading their wings all over the world where they get lots of opportunities to go for "creative" accounting since all countries have different accounting systems which creates ambiguity in investor's mind. Thus, the number of accounting scandals is increasing in India. Over the recent years, "India has developed its corporate-sector, stock-markets and the accounting profession." The growing importance of the corporate-sector calls for its 'efficient' working and 'greater' transparency. However, the prevalence of creative (or fudging) accounting, and fraudulent practices followed by some of the Indian companies hinders this. In spite of number of checks and balances required by regulatory agencies, there have been number of accounting scandals since the 1980s. Firms adopt accounting procedures that "minimizes unfavorable economic effects and enhance favorable ones." The following are some of the motives for fraudulent financial reporting by management: (1) management is under pressure from sources outside or inside the entity, to achieve unrealistic targets, where consequences of failure are very significant, (2) to increase the entity's stock prices or earnings trends, (3) to keep the results attuned to knowingly unrealistic non-achievable forecasts/commitments made to creditors and lenders, (4) tax-motivated reasons, and (5) to raise capital either by the issue of shares at a premium and/or through borrowings [57, pp. 19-23]. Thus, corporate frauds are results of manipulation of accounts and accounting 'jugglery' designed to deceive others for wrongful gains. Such creative accounting by 'fudging' the accounts is attributed to the 'flexibility' provided by the 'accounting' system [44]. The accounting systems in the "Anglo-Saxon" countries have been designed to be flexible enough to accommodate a variety of situations and present them 'fairly' in the accounts. In India, the Companies Act requires that accounts must be "trueand-fair". Sometimes, however, management 'abuses' the freedom of choice in the accounting systems. Methods are adopted to 'hide' the true-picture, and show an 'improved' performance of the firm. Company management may adopt various methods to dress up financial statements to show improved performance. In respect of profit and loss account, the accounting risk is usually the overstatement of income or understatement of expenses. For the balance sheet, it may exist in three areas: the correct valuation of company's assets, accounting for all liabilities and over or understatement of net worth. The effect of creative accounting may defeat the purpose of presentation of "true and fair" financial statements, as required by Section 211 of the Indian Companies Act. Table 3 shows some examples of Indian companies practicing creative accounting from 1996-97 to 2008-09.

Table 3: Creative accounting and fraudulent practices followed by the Indian companies

\begin{tabular}{|c|c|c|}
\hline Company & Years & Nature of Fraud \\
\hline WIPRO Ltd. & $\begin{array}{l}1996-97 \\
\text { to } 1999- \\
2000\end{array}$ & $\begin{array}{l}\text { Transfer of land to stock creating capital reserve with the fair value and using it to neutralize the } \\
\text { effect on profit of reduction of land value. }\end{array}$ \\
\hline Bombay Dyeing \& & 2003-04 & Creating provisions for possible loss on firm purchase contract and subsequent write-back of such \\
\hline Manufacturing Company & and & provision thereby converting operating losses into operating profit. \\
\hline Limited & 2004-05 & \\
\hline Larsen \& Toubro Limited & $\begin{array}{l}1999- \\
2000 \text { and } \\
2001-02\end{array}$ & Income recognition through transfer of loan liabilities at a lower consideration. \\
\hline Apollo Tyres Ltd. & 2004-05 & $\begin{array}{l}\text { Debiting profit and loss account with additional excise duty payable to the government and } \\
\text { transferring equivalent amount from general reserve to neutralize the effect. }\end{array}$ \\
\hline Asian Electronics Ltd. & 2004-05 & Impairment of assets: treatment of deferred tax. \\
\hline $\begin{array}{l}\text { Oil and Natural Gas } \\
\text { Commission, Mukund Ltd., } \\
\text { Torrent Power ACE Ltd. and } \\
\text { Tata Motors Ltd. }\end{array}$ & 2004-05 & $\begin{array}{l}\text { Capitalization of interest as well as other intangible assets to show fixed assets value upward and } \\
\text { understating revenue expenses. }\end{array}$ \\
\hline Hindustan Zinc Limited & $\begin{array}{l}2003-04 \\
\text { and } \\
2004-05\end{array}$ & Reclassifying assets in the balance sheet. \\
\hline $\begin{array}{l}\text { Tata Motors, Bombay Dyeing, } \\
\text { Mahindra and Himachal } \\
\text { Futuristic }\end{array}$ & 2001-02 & Direct write-offs from reserves. \\
\hline $\begin{array}{l}\text { Satyam Computers Services } \\
\text { Limited }\end{array}$ & 2008-09 & $\begin{array}{l}\text { Fraudulently incorporated a non-existent cash component by inflating the bank balances, fudging } \\
\text { bills, accounts receivables, interest, and liabilities. }\end{array}$ \\
\hline
\end{tabular}

Management of the firms could indulge in the above-mentioned practices because of flexibility in accounting standards and other regulatory provisions, thus, leading to fraudulent accounting practices. The best thing about the Satyam episode, as far as investors are concerned, is that it forced more companies to clean up their account books and 
governance practices. The year after the Satyam Computer Services fiasco came to light, corporations were less inclined to indulge in "creative accounting." With the stocks of companies perceived to be flouting prudent CG practicesparticularly real estate companies - taking a beating, India Inc. had little choice but to take notice [52]. In a report, Noble Group (a UK-based investment bank) has evaluated the accounting practices for 313 BSE 500 companies. Sixtythree BSE 500 financial services sector companies were excluded because they do not lend themselves to the 'forensic accounting' techniques used and 124 companies were excluded because their 'consolidated' financial statements for the past two financial years were not available. "We estimate that 20 percent of India's top 500 companies indulge in accounting malpractices, such as recording revenue ahead of time, booking fictitious sales and manipulated cash figures. We find that the incidence of 'creative' accounting has abated in 2008-09, as compared to the previous financial year. This could be due to the corporation's apprehensions after Satyam. This could be because of companies and auditors taking fright following the Satyam scam. It could also be that in a bear market year like 2008-09, when all the stocks were hammered globally, corporation's incentive to flout the accounting rules were muted," says Saurabh Mukherjea, head (Indian equities), Noble Group [Raj, 62, 44]. Unfortunately, this means that as more companies look at tapping the market, the holier-than-thou act that India Inc. has been putting up may be on its way out. If the 'incentive' to cook books is indeed back, investors need to be more careful. The sectors where creative accounting was the most popular in 2007-08 were, as shown in Table 4, housing (including firms related to real estate, construction and cement), information technology, and capital goods (such as companies in construction, power T\&D and materials). In 2008-09, there was a shake-up in the defaulter list. Healthcare replaced IT among the worst performers. Also, the top 50 stocks in the BSE 500 (by market capitalization) were the most likely segment of the market to have a company in Noble's creative accounting "blacklist of the 50 worst companies" for 2008-09. Family-controlled groups also switch funds between their companies for personal gain or to improve stock prices. Many family promoters compromise the interests of shareholders in pursuit of immediate personal wealth accumulation. Check out the consolidated annual statements that a company provides. Pay particular attention to revenue, expense and cash pilferage, the three most common ways of manipulating accounts. Meanwhile the forensic accounting business remains a growth segment, growing at 40-50 percent a year

Table 4: Industry sectors using creative accounting in India

\begin{tabular}{lcc} 
& Table 4: Industry sectors using creative accounting in India & \\
\hline \multicolumn{1}{c}{ Sector } & Per cent of 50 worst companies & Probability of fudging books (in per cent) \\
\hline Housing-related & 16 & 25 \\
Healthcare & 12 & 21 \\
Capital goods & 10 & 14 \\
Metal, metal products and mining & 10 & 21 \\
Information technology & 8 & 12 \\
\hline
\end{tabular}

\section{Forensic accounting provides the connecting link}

What the use of fingerprints was to the 19th century, and DNA analysis was to the 20th century, so financial information and forensic accounting has come to be one of today's most powerful investigative and intelligence tools available. There is no doubt that "qualified, trained and mature accounting professionals, possessing forensic skills, can prove to be a valuable asset to the corporate-sector, and gradually help to improve their CG systems." Initially, forensic accountant's (FA's) were used by the government agencies (such as, the CIA, the FBI, the IRS etc.) to uncover and investigate leading frauds. They became financial detectives-independent experts employed by management to uncover fraudulent financial reporting and misappropriated assets. To combat the frauds effectively one needs the active support of government at every stage. There are three-four such agencies in India, which are dedicated to the mission of combating frauds. Serious Fraud Office looks into violations of Income Tax, FEMA, RBI Act, etc.; CBI (Economic Office Wing) deals with big financial frauds; Central Vigilance Commission deals with corruption are the major government agencies that combat frauds of different types. In the current reporting environment, undoubtedly, FA's are in great demand for their accounting, auditing, legal, and investigative skills. They can play a vital role in coordinating company efforts to achieve a cohesive policy of ethical behavior within an organization.

The definitions of forensic accounting are changing in response to the growing needs of the corporations. Bologna and Lindquist [13] have defined forensic accounting as "the application of financial skills, and an investigative mentality to unresolved issues, conducted within the context of rules of evidence. As an emerging discipline, it encompasses financial expertise, fraud knowledge, and a sound knowledge and understanding of business reality and the working of the legal system." Another view [71] is that "forensic accounting is the comprehensive view of fraud investigation. It includes preventing frauds and analyzing antifraud controls... It also includes the gathering of non-financial information." According to the definition developed by the AICPA's 'Forensic and Litigation Services Committee,' "forensic accounting may involve the application of special skills in accounting, auditing, finance, quantitative methods, the law, and research. It also requires investigative skills to collect, analyze, and evaluate financial evidence, as well as the ability to interpret and communicate findings. Forensic accounting encompasses litigation support, investigation, 
and dispute resolution and, therefore, is the intersection between accounting, investigation and the law." Indeed, forensic accounting includes the use of accounting, auditing and investigative skills to assist in legal matters. Similarly, an author [40] describes as, "Forensic accounting consists of two major components: litigation services that recognize the role of an accountant as an expert consultant, and investigative services that use a forensic accountant's skills and may require possible courtroom testimony." This implies that the FA's should be skilled not only in financial accounting, but also in internal control systems, the law, other institutional requirements, investigative proficiency, and interpersonal skills. Corporations can rely on "FA's skills for developing a consistent system of CG, disseminating such information within and outside the company, ensuring that governance policies and objectives are interwoven into the internal control system, setting up fraud prevention systems, and investigating any existing fraud." The accountants are already trained in many of the skills required for such tasks, but they need some additional specialized skills to the skills of a traditionally trained accountant.

FA's are expected to be a 'specialist' in accounting and financial systems. Yet, as companies continue to grow in size and complexity, 'uncovering' fraud requires FA's to become 'proficient' in an ever-increasing number of "professional skills and competencies". So what personal 'skills' are required to become an efficient FA? So far, several studies have been conducted to find out the core skills and competencies required on the part of FA's. Unfortunately, there is a lack of consensus on this issue.

In addition to the specialized knowledge about the techniques of finding out the frauds, one needs patience and analytical mindset. One has to look beyond the numbers and grasp the substance of the situation. It is basically the work of the intelligent accountants. There is a need for the same basic accounting skills that it takes to become a good auditor plus the ability to pay attention to the smallest detail, analyze data thoroughly, think creatively, possess common business sense, be proficient with a computer, and have excellent communication skills [9]. A "sixth" sense that can be used to reconstruct details of past accounting transactions is also beneficial. A photographic memory helps when trying to visualize and reconstruct these past events. The forensic accountant also needs the ability to maintain his composure when detailing these events on the witness stand. Finally, a forensic accountant should be insensitive to personal attacks on his professional credibility. A fraud accountant (forensic accountant are sometimes called) should also observe and listen carefully. By this, you can improve your ability to detect lies whether they involve fraud or not. This is so because "not all liars are fraudsters, but all fraudsters are liars [73]. It is clear that auditors and professional accountants should have investigative skills in performing their jobs. Consequently, accounting curriculum should consider subjects discussing forensic accounting/auditing. Such curriculum should also be directed to provide students with understanding of organizational culture, business and professional ethics, corporate governance issues, and investigative skills [36, pp. 93-122].

What does the above statement imply for the accounting education? While the forensic accounting/auditing practice had commenced in the U.S. as early as 1995, the seed of this specialization has yet to take off in India. For instance, [38] analyzed the topics covered in internal auditing courses in the United States and Canada, and found that fraud related topics were taught in more than 31 percent of examined internal auditing courses. Similarly, [65] examined the coverage of forensic accounting in the accounting curriculum and found that only a handful of universities offer a fraud and/or forensic accounting course, and suggest that the accounting curriculum provide a knowledge acquisition base in forensic accounting as part of curriculum changes in response to the mandated American Institute of Certified Public Accountants (AICPA) 150-hour accounting program. Unfortunately, almost none of the academic institutions in India are offering a full-course on forensic accounting, either at undergraduate or graduate level, despite the high need for this category of professionals. Most probably, this is on account of lack of information about universally accepted skill-mix of FA's. Both academics and professionals should agree on the required skill-mix of FA's, which could be embedded in their course structures. This scenario, thus, highlights a wide-gap between forensic accounting practice and education in the country.

\section{Review of literature}

In this section, related literatures on the subject matter are briefly reviewed with a view to showing vividly the gap in knowledge. Many researchers have indicated that "technical skills are regarded as implicit in the skills base of a person entering an accounting career, but that it is a range of broader personal characteristics that facilitate career success and make accounting graduates more valuable to employers." Furthermore, long-back Lee and Blaszczynski [47, pp. 104107] suggested that "employers expected accounting students to learn a multitude of skills, not simply how to generate and use accounting information. These skills include being able to communicate, work in a group environment, solve real world problems, and use computer and Internet tools." Aderibigbe [2, pp. 15-20] in his study suggested that "FA's requires high-level of competence, integrity and honesty to perform his job." Moreover, he is of the opinion that FA's must be thoroughly trained, must prove his competence by passing all relevant examinations to become a member of a recognized accountancy body, should always be outstanding in terms of integrity, honesty and probity, and must maintain a professional attitude in the performance of his responsibilities." Similarly, Harris and Brown [41, pp. 2-3] 
have identified "specialized skills and technical abilities of FA's." FA's are usually familiar with criminal and civil law, and understands the courtroom procedures and expectations. These researchers also stressed investigative skills, including theories, methods, and patterns of fraud abuse. FA's thinks creatively to consider and understand the tactics that a fraud perpetrator may use to commit and conceal fraudulent acts. Additionally, they need to clearly and concisely communicate findings to various parties, including those with less knowledge of accounting and auditing.

Rezaee [65] examined a sample of under-graduate and graduate accounting students, and the results indicated that "the students believed that forensic accounting is a viable career option but is not getting the proper attention in Colleges and Universities." However, Grippo and Ibex [37] illustrated that "the most important skills of FA's come from experience in accounting and auditing, taxation, business operations, management, internal controls, interpersonal relationships, and communication." Furthermore, Akers and Porter [4, pp. 65-69] advocated that "the AICPA and the Institute of Management Accountants recognize emotional intelligence skills as critical for the success of the accounting profession." Similarly, Messmer [49, pp. 19-20] stated that "successful FA's must have analytical abilities, strong written and verbal communication skills, a creative mindset, and business acumen. They must be able to interview and elicit information from potentially uncooperative people and possess a strong amount of skepticism." The challenge of delivering graduates with a more extensive and special skill sets is highlighted in a recent 'European' study [Hassall et al, 42, pp. 78-88]. Their research points to similar employer demands for non-technical skills, but reported at the same time that employers were unsympathetic with claims from Universities that they had limited capacity to deliver on these greater demands. Consequently, a special training process can be fashioned out to give interested accounting graduates an opportunity to acquire these special skills that will make them specialists.

Ramaswamy [63, pp. 68-70] believed that "FA's are distinctively positioned to be able to uncover financial deceptions," his prominent skills being an in-depth knowledge of financial statements, the ability to critically analyze them, and a thorough understanding of fraud schemes. He also believed that FA's should have the ability to comprehend the internal-control systems of corporations and be able to assess their risks. The knowledge of psychology helps FA's to understand the impulses behind criminal behavior that motivate and encourage financial deception. Also, interpersonal and communication skills that aid in disseminating information about the company's ethics and an understanding of criminal and civil law and of the legal system and court procedures are skills that aid FA's. Moreover, Rezaee, Crumbley and Elmore [67, pp. 48-59] surveyed opinions of practitioners and academics regarding the importance, relevance, and delivery of forensic accounting education. Their results indicated that "the demand for and the interest in forensic accounting will continue to increase." Their study further shows that both practitioners and academics viewed accounting education as relevant and beneficial to accounting students. However, the groups differed in opinions regarding topical coverage of forensic accounting. In searching for the skill area of FA's, DiGabriele [31, 32] in a US study found that "both academics and practitioners agreed that critical thinking, unstructured problem-solving, investigative flexibility, analytical proficiency, and legal knowledge are important and core skills for FA's."

Ahadiat [3] conducted a study in which he asked respondents to rate the skills expected of an accountant and the auditor. The results from his study shows that "accounting curricula across the United States were revised to include instructions aimed at improving students' knowledge, skills, and abilities, which would go beyond their technical knowledge. These skills included, communication skills, analytical skills, presentation skills, team orientation, critical thinking, among others." However, a study conducted by Sugahara and Coman [72, pp. 1-24] attempted to compare the differences in 'Japanese' accounting faculty and practitioners' perceived importance of generic skills for CPAs in order to assess the CPA Law Amendment of 2003. It was found that "Japanese accounting faculty and practitioners commonly perceived the information skill type as the most important, and the behavioral skill type as the second most important, but they tended to regard the interpersonal skill type as less important." Several implications are also raised from the findings to improve the quality education of Japanese CPAs and also to facilitate the international harmonization of accounting education. Studies by scholars, such as Davis, Farrell and Ogilby [26] and Ekeigwe [33], highlighted that "analytical skill remains the foremost trait that FA's are expected to possess." Their results also revealed that the skill sets of FA's are eclectic. These include general civilization, communication, accounting, business, auditing, technology, psychology, criminology, courtroom behavior, and meta-thinking skills are critical to the effectiveness of a FA. Similarly, in a study conducted by Chukwunedu and Okoye [23] revealed that "forensic accounting techniques injected in an audit and given cost/benefit considerations is capable of increasing the ability of the auditor to detect fraud and thus help bridge the audit expectation gap. This finding has implications for both accounting education and accounting practice.

It is apparent that the "academic literature has identified some of the forensic accounting courses and course contents, whereas the practitioner literature suggests core skills necessary in practice." However, the literature has not yet empirically identified the views of three major stakeholders-accounting academics, forensic accounting practitioners, and users of forensic accounting services — regarding which skills are important for FA's. All the three stakeholders will be significant in shaping the future of forensic accounting. An attempt is made here "to uncover the basic skills needed for traditional accounting and auditing services, and the ones required for specialized services in the areas of fraud investigations, forensic accounting and forensic auditing." 


\section{Objective of the study}

The 'primary' objective of this study is 'to assess the necessary skills required by forensic accountants (FA's) in India and make a case for the development of a standardized curriculum for the study of forensic accounting as a course in the Universities." However, three 'specific' objectives are:

1) To determine the extent to which financial and economic crimes have impacted on the Indian economy and the effectiveness of forensic accounting functions;

2) To establish the need for incorporating forensic accounting courses in the academic curriculum of Indian Universities; and

3) To determine whether the necessary skills required by the FA's in the developed countries significantly differs from the expectations of clients and accountants in India.

\subsection{Hypothesis formulation}

To achieve our primary objective, the following three propositional and non-affirmative hypotheses are formulated and statements made:

1) Hypothesis: "Core skills are not enough requirements for FA's to investigate economic and financial crimes in the Indian economy;"

2) Hypothesis: "There are no significant differences in the relevant skills of FA's as given by previous researchers with the current research study;" and

3) Hypothesis: "The necessary skills of FA's, as identified by both academics and professionals, Will not meet the employers' expectations."

\subsection{Research methodology}

During 2011-12, we conducted a survey of three States in the National Capital Region (NCR viz., Delhi, Gurgaon and Ghaziabad) of India using a random sample of 120 practicing accountants, accounting academics, and users/potential users of forensic accounting services. This study classified lawyers and anti-graft agencies personnel as the primary users of forensic accounting services. The research instrument (or questionnaire) was divided into three sections, and it was sent out and retrieved as follows: 120 questionnaires were given hand-to-hand by trained assistants to members of the stakeholders' groups. 40 for each group of professional accountants, accounting academics and lawyers/anti-graft agencies personnel. However, only 70 questionnaires were finally retrieved as per schedule, with 65 found to be reasonably complete in most respects.

We prepared and pre-tested our survey instrument before sending it out to all our respondents. The questionnaire was structured into three Sections. In Section a, first-six questions attempted to map the biographical profile of the respondents, such as, primary profession, gender, education, experience, professional qualification/license, and involvement with forensic accounting services. Here, one question specifically asked the participants to "identify, at least, five core skills (out of 19 skill options) that FA's needs to possess, and rank them on a 5-point Likert-type scale, ranging from 4 (strongly agree) to 0 (strongly disagree)." Similarly, in Section B, 9 skill-related broad statements were presented being the important skills of FA's. As suggested by DiGabrielle [31, pp. 331-338], “The 9 skills required for the FA's to be rated were: deductive analysis, critical thinking, unstructured problem-solving, investigative flexibility, analytical proficiency, oral and written communication, specific legal knowledge and composure. You are expected to answer them on a 5-point Likert-type scale, ranging from ranging from 4 (strongly agree), 3 (Agree), 2 (Neutral), 1 (disagree) to 0 (strongly disagree)." Moreover, in Section C, we asked the respondents to answer some questions regarding basic education and career-paths of FA's, their likely demand in the future - next 5, 10 and 20 years, and need to know computer-based forensic techniques and software tools." The scales were anchored at each end with the descriptors "extremely unimportant" to "extremely important," respectively. The responses from the above stated aspects of the survey instrument enabled us to assess participants views on the 'core' skills of FA's, the extent of differences in views about these skills between current and previous research, and general trends about FA's education, career-path, demand-supply scenario, and computer-proficiency.

Some Universities in India are considering including forensic accounting courses to their curriculum. This evolution has unearthed an absence regarding the significant skill-set outcome that should accompany forensic accounting education. One of the objectives of this study is to examine the necessary skills that will be required by would-be FA's for the purpose of recommending them to Indian Universities for possible inclusion in their syllabi. The current study complements the two prior-studies [66, 67] by surveying "forensic professionals for their perceptions of the necessary skills and characteristics for FA, as well as the education requirements."

In conducting the data analysis, we used SSPS and Excel packages to compute descriptive statistics for group membership (tables of frequencies and percentages) as well as the responses relating to the 19 competencies (both 
percentages within each category and overall means, standard deviations, variances and ranges). Moreover, the correlations among the 19 items were also computed. The main set of analyses that were followed consist of a series of one-way Analyses of Variances (ANOVAs) comparing the views of FA's, academics, lawyers/anti-graft agencies personnel in terms of their ratings of the importance of all the competencies. Specifically, the one-way ANOVA was used for testing hypothesis one, T-test for testing hypothesis two and chi-square (x2) for testing hypothesis three.

\section{Data analysis, findings and results}

A total of 65 respondents fully-completed the survey instrument, of them 20 (31\%) were professional/forensic accountants, $20(31 \%)$ accounting academics, and $25(38 \%)$ were users of forensic accounting services. The overall response rate was 54 percent, which is little above the average score. The demographic profile of the sample is as follows: approximately 70 percent of the sample comprised of men, 62 percent were over the age of 40 years, 93 percent were having undergraduate/masters' education, 77 percent were having experience with business forensics, 88 percent had experience with accounting, and 92 percent had experience with auditing, respectively.

As stated earlier, our survey instrument (i.e., questionnaire) was divided into three Sections. In Section A, the list of choices provided to the participants was developed through an extensive review of the relevant academic and professional literature, consultation with forensic accounting practitioners, and users of forensic services. Based on the outcome of the current study, descriptive statistics for the 19 areas of skill competency, including the overall means, standard deviations, variances, and ranges are shown in Table 5. It should be noted here that the "skills with the high means and low standard deviations are the most important skills required for FA's, while the skills with low means but high standard deviations are the least important skills required to be FA's." Based on the findings of the present study, we can conclude as follows: "The skill competency items rated as the most important were effective written communication $(\mathrm{M}=15.5, \mathrm{SD}=5.1)$, auditing skills and oral communication $(\mathrm{M}=14.75, \mathrm{SD}=6.7$ \& 5.2). Research skills $(M=13.75, S D=6.8)$, tell the story, and investigative ability $(M=13.5 \& 13.25, S D=4.4 \& 3.6)$ take the second position in terms of importance. The items rated as least important were: understanding the goal of a case $(\mathrm{M}=6.5, \mathrm{SD}=2.9)$, solve unstructured problems $(\mathrm{M}=10, \mathrm{SD}=3.6)$, and synthesize results of discovery and analysis $(\mathrm{M}=10, \mathrm{SD}=5.4)$, respectively."

The correlations among the important ratings for the 19 skill-competencies are shown in Table 6. The following general observations can be made: "The highest correlations were between Critical thinking-Sociology-Understanding the goal of the case, Effective written communication-Psychology, Investigative ability-Simply the information, Organizing an unstructured situation-Solve structured problems-Solve unstructured problems, Simply the information-Tell the story, Solve structured problems-Solve unstructured problems-Psychology skills, and Understand the goals of a caseSociology, all with 99 percent $(r=0.99)$ and between Critical/strategic thinker- Solve unstructured problems, Effective written communicating-Solve unstructured problems, Organizing an unstructured situation-Research Skills-Psychology skills, and Simply the information-Solve structured problems all with 98 percent $(r=98)$, whereas the lowest was Understand the goals of a case with 36 percent $(r=0.36)$. However, most of the correlations were above 50 percent $(r=$ $0.50)$, thus, showing reasonable levels of statistical significance."

Table 5: Descriptive statistics for skill competency required for forensic accountants

\begin{tabular}{|c|c|c|c|c|c|}
\hline & Skills Required for FA's & Mean & Standard Deviation & Variance & Range \\
\hline 1. & Auditing Skills & 14.75 & 6.7 & 44.9 & 15 \\
\hline 2. & Critical/strategic thinker & 10.25 & 6.2 & 38.9 & 15 \\
\hline 3. & Effective oral communication & 14.75 & 5.2 & 26.9 & 11 \\
\hline 4. & Effective written communication & 15.5 & 5.1 & 25.7 & 11 \\
\hline 5. & Identify key issues & 10.25 & 5.9 & 34.9 & 13 \\
\hline 6. & Investigative ability & 13.25 & 3.6 & 12.9 & 8 \\
\hline 7. & Investigative intuitiveness & 12 & 4.2 & 18.0 & 9 \\
\hline 8. & Organize an unstructured situation & 12.25 & 6.6 & 43.6 & 14 \\
\hline 9. & Research Skills & 13.75 & 6.8 & 45.6 & 15 \\
\hline 10. & Legal skills & 11.75 & 4.6 & 21.6 & 10 \\
\hline 11. & Simply the information & 12 & 4.2 & 18.0 & 9 \\
\hline 12. & Solve structured problems & 11.25 & 4.3 & 18.3 & 9 \\
\hline 13. & Solve unstructured problems & 10 & 3.6 & 12.7 & 8 \\
\hline 14. & Synthesize results of discovery and analysis & 10 & 5.4 & 28.7 & 11 \\
\hline 15. & Tell the story & 13.5 & 4.4 & 19.0 & 9 \\
\hline 16. & Think like the wrongdoer & 11.25 & 4.3 & 18.9 & 10 \\
\hline 17. & Understand the goals of a case & 6.5 & 2.9 & 8.3 & 7 \\
\hline 18. & Others: Psychology skills & 10.5 & 3.1 & 9.7 & 7 \\
\hline 19. & Others: Sociology skills & 8.75 & 3.8 & 14.3 & 9 \\
\hline
\end{tabular}


Table 6: Correlation analysis

\begin{tabular}{|c|c|c|c|c|c|c|c|c|c|c|c|c|c|c|c|c|c|c|c|}
\hline Tyne of Skill & 1 & 2 & 3 & 1 & 5 & 6 & 7 & 8 & 0 & 10 & 11 & 17 & 12 & 14 & 15 & 16 & 17 & 18 & 10 \\
\hline & 1 & 2 & 3 & 4 & 3 & 0 & 1 & 0 & 9 & 10 & 11 & 12 & 13 & 14 & 15 & 10 & 17 & 18 & 19 \\
\hline Auditing & 1.0 & & & & & & & & & & & & & & & & & & \\
\hline Skills & 0 & & & & & & & & & & & & & & & & & & \\
\hline Critical/strate & 0.8 & 1.0 & & & & & & & & & & & & & & & & & \\
\hline gic thinker & 9 & 0 & & & & & & & & & & & & & & & & & \\
\hline Effective oral & 0.4 & 0.7 & 1.0 & & & & & & & & & & & & & & & & \\
\hline $\begin{array}{l}\text { communicato } \\
\text { r }\end{array}$ & 3 & 2 & 0 & & & & & & & & & & & & & & & & \\
\hline Effective & 0.9 & 0.9 & 0.7 & 1.0 & & & & & & & & & & & & & & & \\
\hline $\begin{array}{l}\text { written } \\
\text { communicato } \\
\text { r }\end{array}$ & 1 & 4 & 6 & 0 & & & & & & & & & & & & & & & \\
\hline Identify key & 0.5 & 0.8 & 0.9 & 0.8 & 1.0 & & & & & & & & & & & & & & \\
\hline issues & 6 & 5 & 7 & 3 & 0 & & & & & & & & & & & & & & \\
\hline Investigative & 0.8 & 0.7 & 0.6 & 0.9 & 0.6 & 1.0 & & & & & & & & & & & & & \\
\hline ability & 7 & 8 & 6 & 4 & 7 & 0 & & & & & & & & & & & & & \\
\hline Investigative & 0.7 & 0.6 & 0.6 & 0.8 & 0.6 & 0.9 & 1.0 & & & & & & & & & & & & \\
\hline intuitiveness & 7 & 8 & 7 & 8 & 4 & 8 & 0 & & & & & & & & & & & & \\
\hline Organizing an & 0.9 & 0.9 & 0.6 & 0.9 & 0.7 & 0.9 & 0.8 & 1.0 & & & & & & & & & & & \\
\hline $\begin{array}{l}\text { unstructured } \\
\text { situation }\end{array}$ & 8 & 4 & 0 & 7 & 1 & 1 & 2 & 0 & & & & & & & & & & & \\
\hline Research & 0.9 & 0.9 & 0.7 & 1.0 & 0.8 & 0.9 & 0.8 & 0.9 & 1.0 & & & & & & & & & & \\
\hline Skills & 3 & 7 & 4 & 0 & 3 & 2 & 4 & 8 & 0 & & & & & & & & & & \\
\hline Legal Skills & 0.6 & 0.6 & 0.6 & 0.7 & 0.6 & 0.9 & 0.9 & 0.7 & 0.6 & 1.0 & & & & & & & & & \\
\hline & 8 & 9 & 7 & 4 & 2 & 2 & 6 & 0 & 9 & 0 & & & & & & & & & \\
\hline Simply the & 0.8 & 0.8 & 0.7 & 0.9 & 0.7 & 0.9 & 0.9 & 0.9 & 0.9 & 0.8 & 1.0 & & & & & & & & \\
\hline information & 9 & 7 & 3 & 8 & 6 & 9 & 5 & 5 & 7 & 5 & 0 & & & & & & & & \\
\hline Solve & 0.9 & 0.9 & 0.6 & 0.9 & 0.7 & 0.9 & 0.8 & 0.9 & 0.9 & 0.7 & 0.9 & 1.0 & & & & & & & \\
\hline $\begin{array}{l}\text { structured } \\
\text { problems }\end{array}$ & 5 & 3 & 8 & 9 & 6 & 5 & 8 & 9 & 9 & 6 & 8 & 0 & & & & & & & \\
\hline Solve & 0.9 & 0.9 & 0.6 & 0.9 & 0.7 & 0.8 & 0.7 & 0.9 & 0.9 & 0.6 & 0.9 & 0.9 & 1.0 & & & & & & \\
\hline $\begin{array}{l}\text { unstructured } \\
\text { problems }\end{array}$ & 6 & 8 & 6 & 8 & 8 & 9 & 9 & 9 & 9 & 5 & 4 & 9 & 0 & & & & & & \\
\hline Synthesize & 0.9 & 0.9 & 0.3 & 0.8 & 0.5 & 0.7 & 0.5 & 0.9 & 0.8 & 0.4 & 0.7 & 0.8 & 0.9 & 1.0 & & & & & \\
\hline $\begin{array}{l}\text { results of } \\
\text { discovery and } \\
\text { analysis }\end{array}$ & 6 & 1 & 7 & 4 & 5 & 1 & 7 & 3 & 7 & 4 & 7 & 7 & 3 & 0 & & & & & \\
\hline Tell the story & 0.8 & 0.8 & 0.7 & 0.9 & 0.7 & 0.9 & 0.9 & 0.9 & 0.9 & 0.8 & 0.9 & 0.9 & 0.9 & 0.7 & 1.0 & & & & \\
\hline & 4 & 3 & 6 & 7 & 7 & 9 & 7 & 1 & 4 & 8 & 9 & 6 & 0 & 0 & 0 & & & & \\
\hline Think like the & 0.6 & 0.7 & 0.9 & 0.9 & 0.8 & 0.9 & 0.9 & 0.8 & 0.8 & 0.8 & 0.9 & 0.8 & 0.8 & 0.5 & 0.9 & 1.0 & & & \\
\hline wrongdoer & 8 & 8 & 0 & 2 & 8 & 1 & 2 & 0 & 8 & 0 & 3 & 7 & 2 & 4 & 6 & 0 & & & \\
\hline Understand & 0.8 & 0.9 & 0.6 & 0.8 & 0.8 & 0.6 & 0.5 & 0.9 & 0.9 & 0.3 & 0.7 & 0.8 & 0.9 & 0.9 & 0.7 & 0.7 & 1.0 & & \\
\hline $\begin{array}{l}\text { the goals of a } \\
\text { case }\end{array}$ & 5 & 9 & 8 & 9 & 3 & 9 & 7 & 0 & 2 & 6 & 9 & 8 & 4 & 1 & 4 & 0 & 0 & & \\
\hline Others: & 0.9 & 0.9 & 0.7 & 0.9 & 0.8 & 0.9 & 0.8 & 0.9 & 1.0 & 0.6 & 0.9 & 0.9 & 0.9 & 0.8 & 0.9 & 0.8 & 0.9 & 1.0 & \\
\hline $\begin{array}{l}\text { Psychology } \\
\text { skills }\end{array}$ & 3 & 7 & 3 & 9 & 3 & 1 & 3 & 8 & 0 & 8 & 6 & 9 & 9 & 8 & 3 & 8 & 3 & 0 & \\
\hline Others: & 0.9 & 0.9 & 0.6 & 0.9 & 0.8 & 0.7 & 0.6 & 0.9 & 0.9 & 0.4 & 0.8 & 0.9 & 0.9 & 0.9 & 0.7 & 0.7 & 0.9 & 0.9 & 1.0 \\
\hline $\begin{array}{l}\text { Sociology } \\
\text { skills }\end{array}$ & 0 & 9 & 5 & 2 & 0 & 4 & 2 & 4 & 5 & 3 & 3 & 1 & 7 & 4 & 8 & 2 & 9 & 5 & 0 \\
\hline
\end{tabular}

Testing of Hypotheses: To fully achieve our primary objective, propositional statements are tested here:

Hypothesis-1: "Core skills are not enough requirements for Forensic Accountants (FA's) to investigate economic and financial crimes in India."

The p-value of 0.655 (as shown in Table 7.1) is greater than our 0.05 level of significance, the 'null' hypothesis will be accepted, while the alternative rejected.

In Section B, most of the questions asked to the participants of this study have been suggested by DiGabrielle (2008) to be the important skills of forensic accountants (FA's). The respondents were expected to answer them on a 5-point Likert-type scale, ranging from 4 (strongly agree), 3 (Agree), 2 (Neutral), 1 (disagree) to 0 (strongly disagree).

Here, nine questions were asked to practitioners, academics, and users of forensic accounting services that pertain to soliciting their views on "what skills are deemed to be inherently important for forensic accountants (FA's)." The first question asked to the respondents was: "An important skill requirement of a FA is 'Deductive Analysis'- the ability to aim at financial contradictions that do not fit in the normal pattern of an assignment." An expert witness must be able to discern fact from fiction to maintain 'credible' testimony. Courses developed in this area should emphasize the ability to remove any non-corroborated opinions from expert reports and testimony. This skill was rated as one of the more important ones. Not surprisingly, $87.5 \%$ academics and practitioners agreed that this is an important skill of FA's. In consideration of the barrage of recent financial reporting scandals across the globe, this skill appears to be necessary 
and essential for FA's to meet the objective of uncovering a potential financial fraud. Thus, forensic accounting courses taking aim at financial misrepresentations should incorporate course objectives to meet this ability.

\begin{tabular}{|c|c|c|c|c|}
\hline Groups & Count & Sum & Average & Variance \\
\hline Auditing Skills & 4 & 59 & 14.75 & 44.91666667 \\
\hline Critical/strategic thinker & 4 & 41 & 10.25 & 38.91666667 \\
\hline Effective oral communicator & 4 & 59 & 14.75 & 26.91666667 \\
\hline Effective written communicator & 4 & 62 & 15.5 & 25.66666667 \\
\hline Identify key issues & 4 & 41 & 10.25 & 34.91666667 \\
\hline Investigative ability & 4 & 53 & 13.25 & 12.91666667 \\
\hline Investigative intuitiveness & 4 & 48 & 12 & 18 \\
\hline Organize an unstructured situation & 4 & 49 & 12.25 & 43.58333333 \\
\hline Research Skills & 4 & 55 & 13.75 & 45.58333333 \\
\hline Legal Skills & 4 & 47 & 11.75 & 21.58333333 \\
\hline Simply the information & 4 & 48 & 12 & 18 \\
\hline Solve structured problems & 4 & 45 & 11.25 & 18.25 \\
\hline Solve unstructured problems & 4 & 40 & 10 & 12.66666667 \\
\hline Synthesize results of discovery and analysis & 4 & 40 & 10 & 28.66666667 \\
\hline Tell the story & 4 & 54 & 13.5 & 19 \\
\hline Think like the wrongdoer & 4 & 45 & 11.25 & 18.91666667 \\
\hline Understand the goals of a case & 4 & 26 & 6.5 & 8.333333333 \\
\hline Others: Psychology skills & 4 & 42 & 10.5 & 9.666666667 \\
\hline Others: Sociology skills & 4 & 35 & 8.75 & 14.25 \\
\hline
\end{tabular}

\begin{tabular}{llllll}
\multicolumn{5}{c}{ Table 7.1: ANOVA (Summary) } \\
\hline Source of Variation & SS & Df & MS & F & P-value \\
\hline Between Groups & 363.789 & 18 & 20.211 & 0.833 & 0.655 \\
Within Groups & 1382.25 & 57 & 24.25 & & \\
Total & 1746.039474 & 75 & & & \\
\hline
\end{tabular}

The second question asked to the participants was: “An important skill requirement of a FA is 'Critical Thinking' - the ability to decipher between opinion and fact." The essence of being an expert witness is to be able to perform the task of discerning fact from fiction in order to maintain a credible testimony. Critical thinking skills are essential to understanding, applying, and adapting concepts and principles in a variety of contexts and circumstances. The FA's professional skepticism of questioning management's responses involves critical thinking that entails an attitude of examining and recognizing emotion-laden and explicit or hidden assumptions behind each question. FA's must master critical thinking skills because business organizations continue to evolve in response to new IT and greater worldwide competition. Fundamentally, computer fraud is people fraud, and the required computer skills will vary greatly depending on the type of fraud being perpetrated. Frauds such as data diddling require only basic skills; on the other hand, theft of information in a secure database will require more advanced computer skills from the fraudster [8, pp. 7586]. In addition to rendering of 'traditional' accounting services, FA's are nowadays involved in fast evolving services, such as, attestation reviews, forensic accounting, and fraud examinations. Today's FA's must thus, possess the knowledge to remain updated and the skills to critically analyze various problems. Courses developed in this area should emphasize to students the ability to remove any non-corroborated opinions from expert reports and testimony. While critical thinking is necessary for FA's in today's business world, cultivating students' critical thinking skills in an accounting classroom can be a challenge [18, pp. 655-675]. Table-8 illustrates this skill was rated as one of the more important $(100 \%)$ by all.

The third question asked was: "An important skill requirement of a FA is 'Unstructured Problem Solving' - the ability to approach each situation (inherently unique) and be prepared to solve problems with an unstructured approach." Academics and practitioners agreed $(70 \%)$ that problem-solving is an important skill of a FA. Accounting education has been based around concentrating on compliance with rules and procedures. However, forensic accounting is different because problem-solving becomes more of an 'improvised' approach rather than a 'structured' plan. This skill type is in direct opposition to the traditional accounting skills. It can be argued that a shortcoming of auditors is "not seeing the proverbial forest beyond the trees." The fourth question asked: "An important skill requirement of a FA is "Investigative Flexibility' - the ability to move away from standardized audit procedures and thoroughly examined situations for a typical warning signs." The results of this study indicate that practitioners and academics agree (80\%) on the importance of this skill, thus, further illustrating the need in accounting for a more 'open-minded' skill set. The results of the present study indicate that potential practitioners and academics agreed on the importance of FA's moving away from a 'narrow' approach and applying a more 'holistic' technique. These findings further illustrate the need for a more open-minded skill set in accounting. Considering the post-financial-fraud regulatory environment, researchers can infer 
that the ability to solve a financial puzzle with an incomplete set of pieces is an extremely important characteristic for FA's. Practitioner and academics agree on the importance of this skill.

The fifth question asked to participants was: “An important skill requirement of a FA is 'Analytical Proficiency' — the ability to examine for what should be provided rather than what is provided." Analytics can be of use to FA's because they often reveal unusual relationships that need to be carefully examined. Consequently, the post-financial fraud regulatory environment, solving a financial puzzle with less than a complete set of pieces appears to be the direction the current business environment is heading. Practitioners and academics agree (75\%) on the importance of this skill. Question six asked: “An important skill requirement of a FA is 'Oral Communication' - the ability to effectively communicate in speech via expert testimony and general explanation; the bases of opinion." Part of the job of the FA is to go into the field and speak to company personnel, who may or may not be involved with the suspected fraud. In addition, they are often called to be expert 'witnesses' and testify during litigation, presenting often complex evidence to the jury in an understandable manner [69, pp. 231-235]. Almost 95\% of all respondents strongly agree that oral communication is an important skill of a FA. The seventh question asked was: "An important skill requirement of a FA is 'Written Communication'- the ability to effectively communicate in writing via reports, charts, graphs, and schedules; the bases of opinion." Indeed, a FA needs to document their work. A well-written report by a FA can be a vital tool in litigation, and may help to impress the judge/jury [24]. All groups 'agreed' (100\%) on the importance of this skill, with $60 \%$ of all respondents 'strongly agreeing'. Almost $95 \%$ of all respondents strongly agreed that oral communication is an important skill for FA's, as shown above in Table 6. This skill is particularly important in expert testimony when a FA explains findings to a judge and panel of judges. Each group agreed on the importance of FA possesses the ability to effectively communicate in writing, and $100 \%$ of all respondents agreed strongly. Expert reports are routinely scrutinized and the need to convey findings properly is of paramount importance. The ability to communicate effectively, in both oral and written forms, is essential for today's practitioners.

In the eighth question participants/respondents were asked: "An important skill requirement of a FA is "Specific Legal Knowledge' - the ability to understand basic legal processes and legal issues including the rules of evidence." Academics and practitioners agreed and strongly agreed (97.5\%) that this is an important skill of FA's. One of the interesting results of this study is the fact that 'users' of forensic accounting services did not view this as an important skill. The reason for this can only be speculated. Since the users were attorneys, they may have read too far into the question possibly thinking FA's may practice law without proper licensing. However, the main point of the question was to emphasize the need for FA's to understand certain legal issues. Academics and potential practitioners agreed that FA's should have a working knowledge of the legal process and the rules of evidence. Despite a traditional advocacy role, tax professionals face growing pressure to help manage the tax-fraud problem. [29, pp. 289-306].

Finally, the last (ninth) question asked the participants: "An important skill requirement of a FA is 'Composure'-the ability to maintain a calm attitude in pressured situations." The groups did not differ in opinion of this skill. All groups 'agreed' $(100 \%)$ on the importance of this skill, with $75 \%$ of all respondents 'strongly agreeing'. The most prevalent area where this is necessary is expert testimony in either deposition or court. The composure of an expert can be an integral component in the ultimate case outcome. From our test of hypothesis, it has been discovered that accountants require special skills to work as FA's and fraud investigators. Perhaps, this is so in view of the prevalent nature of corruption and scandals in the country. The tenth question asked the participants to identify themselves as a practitioner, academics, or a user of forensic accounting services. All the respondents agreed that maintaining composure is an important skill for FA's

Descriptive statistics for the nine areas of competencies are shown in Table-8. The items rated as "the 'most' important were critical thinking, written communication and composure (100\% each), followed by specific legal knowledge $(97.5 \%)$, oral communication $(95 \%)$ and deductive analysis $(87.5 \%)$." However, the items rated as 'least' important were "investigative flexibility (80\%), analytical proficiency $(75 \%)$ and unstructured problem solving (70\%)." The findings of our study are, more or less, similar to a survey [48, pp. 30-48], which concluded, "The skill ranked 'highest' in terms of importance is analytical skills, followed closely by basic accounting skills, problem-solving skills, and data analysis skills. The 'characteristic' ranked 'highest' in terms of importance are persistence and skepticism, followed closely by puzzles and people skills." Thus, the identification of relevant skills of FA's illustrated in the results of this study would contribute to progress the literature in forensic accounting education by identifying the necessary proficiencies to be merged with the accounting course contents. 
Table 8: Percentage of respondents choosing each competency skill item

\begin{tabular}{|c|c|c|c|c|c|c|c|}
\hline \multirow[t]{2}{*}{ Item } & $\begin{array}{l}\text { Strongly } \\
\text { Disagree }\end{array}$ & Disagree & Neutral & Total & Agree & $\begin{array}{l}\text { Strongly } \\
\text { Agree }\end{array}$ & Total \\
\hline & $(0)$ & (1) & (2) & $(0,1,2)$ & (3) & (4) & $(3,4)$ \\
\hline Deductive Analysis & 0.0 & 5.0 & 7.5 & 12.5 & 30.0 & 57.5 & 87.5 \\
\hline Critical Thinking & 0.0 & 0.0 & 0.0 & 0 & 25.0 & 75.0 & 100 \\
\hline Unstructured Problem Solving & 8.3 & 8.3 & 13.4 & 30 & 22.5 & 47.5 & 70 \\
\hline Investigative Flexibility & 0.0 & 0.0 & 20.0 & 20 & 16.6 & 63.4 & 80 \\
\hline Analytical Proficiency & 0.0 & 16.7 & 8.3 & 25 & 16.7 & 58.3 & 75 \\
\hline Oral Communication & 0.0 & 8.3 & 8.3 & 5 & 41.7 & 41.7 & 95 \\
\hline Written Communication & 0.0 & 0.0 & 0.0 & 0 & 41.7 & 58.3 & 100 \\
\hline Specific Legal Knowledge & 0.0 & 0.0 & 8.3 & 2.5 & 50.0 & 41.7 & 97.5 \\
\hline Composure & 0.0 & 0.0 & 0.0 & 0 & 25.0 & 75.0 & 100 \\
\hline
\end{tabular}

The correlation analysis, which was subsequently validated by t-test, became a prerequisite for either accepting our null hypothesis that says, "Special skills are not required for forensic accounting investigations," or rejecting it and accepting the alternative hypotheses that says in the affirmative direction.

The general set up for the testing of this hypothesis, using the correlation coefficient, is as follows: Null Hypothesis (Ho); Alternative Hypothesis (H1); and the Statistical Test:

$\mathrm{Rxy}=\left(\sum \mathrm{X} 2+\sum \mathrm{Y} 2-\sum \mathrm{Di} 2\right) /\left\{2 \sqrt{ }\left(\left(\sum \mathrm{X} 2 \mathrm{x}\left(\sum \mathrm{Y} 2\right)\right\}\right.\right.$

While $\mathrm{t}=\operatorname{rxy} \sqrt{(\mathrm{n}-2) / \sqrt{ }\{1-(\operatorname{rxy}) 2\}}$

Rxy $=0.5385$ and $t=1.6908$

Decision Rule at $0.10(\alpha)$ significance level or $90 \%$ confidence level is given thus:

Reject H0: if $/ \mathrm{t} / \mathrm{-}$ calculated $\geq \mathrm{t}$-tabulated () , and $/ \mathrm{t} /=1.6908$. While $\mathrm{t}()$ at $(\mathrm{n}-2) \mathrm{df}=1.415$, where $\mathrm{n}=9$. But $1.6908>$ 1.415 , that means, t-test calculated is greater than $\mathrm{t}$-test tabulated. Therefore, our H0 is rejected while the alternative hypothesis (H1), which says, "Special skills are required for forensic accounting investigations" is upheld.

Again, our test of statistics for the second hypothesis shows that "there are significant differences in the relevant skills of FA's, as given by previous researchers with the current research." This is a confirmation to the result obtained from testing the 'first' hypothesis which shows that core skills are not enough requirements for forensic accounting practice. Most of the early researchers [31, pp. 331-338], who have researched in this area has focused on the 'core' skills of FA's. Finally, our test of hypothesis clearly states that necessary skills of FA's, as identified by both academics and professionals, will hopefully meet employers' expectations too. Employers, who include lawyers and anti-graft agencies personnel, are the ultimate users of forensic accounting services, and if they concur with what accounting academics and professionals say should be the skill requirement of FA's, then academic and professional institutions should not hesitate to incorporate these skills in their curricula.

\section{$7 \quad$ Hypothesis testing}

Hypothesis-2: There are no significant differences in the relevant skills of FA's as given by previous researchers with the current research.

Table 9: Testing using t-test statistics (two-sample assuming unequal variances)

\begin{tabular}{lll}
\hline & Previous & Current \\
\hline Mean & 53.64285714 & 46.78947368 \\
Variance & 92.09340659 & 80.84210526 \\
Observations & 14 & 19 \\
Hypothesized Mean Difference & 0 & 27 \\
Df & 2.082244389 & 0.023462566 \\
t-Stat & 1.703288423 & 0.046925132 \\
P $(\mathrm{T}<=t)$ one-tail & 2.051830493 \\
P(T<=t) two-tail & \\
T Critical two-tail & \\
\hline
\end{tabular}

The calculated p-values for both the one and the two-tail are 0.0235 and 0.0470 , respectively as shown in Table 9 . These are less than both the 5\% level of significant and the table values of 1.703 and 2.052, respectively. This shows that the "null" hypothesis should be rejected while the alternate hypothesis that says "there are significant differences in the relevant skills of Forensic Accountants (FA's), as given by previous researchers with the current research" be accepted.

Hypothesis-3: "The necessary skills of FA's as identified by both academics and professionals

Will not meet employers' expectations."

Table 10 and 10.1 show the details of the chi-square tool used for testing this hypothesis. 
If the p-value is greater than the level of significance, accept $\mathrm{H} 0$ and reject $\mathrm{H} 1$, otherwise reject $\mathrm{H} 0$ and accept $\mathrm{H} 1$. In this case, the p-value $=0.000$ and the level of significance is 0.050 , therefore, we accept H1 which says "the necessary skills of Forensic Accountants as identified by both academics and professionals will meet employers' expectations" and reject $\mathrm{H} 0$.

Finally, in Section C of our questionnaire, we asked the respondents to answer some questions regarding "education for and typical career-paths of FA's." First, we asked them, "Other than accounting, what undergraduate degree major do you think is most appropriate for a forensic accountant (FA)?" Sixty percent of the respondents answered "computer information systems" and twenty-seven percent answered "legal studies." Table 11 presents the results for this question. We also asked, "What is the highest-level of education that you think is needed to be a successful FA?" Fifty-nine percent of the participants indicated that an undergraduate degree is the highest-degree necessary, while thirty-nine percent felt that a master's degree is necessary. Finally, participants were asked, "What is the typical career-path for a FA in your firm?" Forty-three percent indicated that the typical career path is to graduate with a degree in accounting and start in the audit department of the firm.

Table 10: Testing using chi-square ( $\mathrm{x} 2)$

What is your involvement with forensic accounting services? $*$

What licenses or professional qualifications do you possess? Cross-tabulation

\begin{tabular}{|c|c|c|c|c|c|c|c|}
\hline \multicolumn{8}{|l|}{ Count } \\
\hline & & \multicolumn{5}{|c|}{ What licenses or professional qualifications do you possess? } & \multirow[t]{2}{*}{ Total } \\
\hline & & $\begin{array}{l}\mathrm{ACCA} \text { or } \\
\mathrm{CA}\end{array}$ & CFA & $\mathrm{CFE}$ & $\begin{array}{l}\text { Attorney at } \\
\text { Law }\end{array}$ & Others & \\
\hline \multirow{4}{*}{$\begin{array}{l}\text { What is your involvement } \\
\text { with forensic accounting } \\
\text { services? }\end{array}$} & $\begin{array}{l}\text { I undertake services of forensic } \\
\text { accountants }\end{array}$ & 9 & 0 & 0 & 0 & 0 & 9 \\
\hline & $\begin{array}{l}\text { I consider myself a forensic } \\
\text { accountant }\end{array}$ & 14 & 2 & 2 & 0 & 0 & 18 \\
\hline & $\begin{array}{l}\text { I employ forensic accountants in } \\
\text { my firm chambers }\end{array}$ & 5 & 0 & 0 & 0 & 0 & 5 \\
\hline & I have no involvement & 6 & 0 & 2 & 21 & 4 & 33 \\
\hline \multicolumn{2}{|l|}{ Total } & 34 & 2 & 4 & 21 & 4 & 65 \\
\hline
\end{tabular}

Table11.1: Chi-square tests

\begin{tabular}{llll}
\hline & Value & Df & Asymp. Sig.(2-sided) \\
\hline Pearson Chi-Square & $57.469^{\mathrm{a}}$ & 12 & 0.000 \\
Likelihood Ratio & 74.881 & 12 & 0.000 \\
Linear-by-Linear Association & 42.829 & 1 & 0.000 \\
No. of Valid Cases & 65 & \\
\hline a. 16 cells $(80.0 \%)$ have expected count less than 5. The minimum expected count is 0.15. &
\end{tabular}

Table 11: Education

\begin{tabular}{ll}
\hline Undergraduate degree major most appropriate & Percent \\
\hline Computer Information Systems & 60.4 \\
Economics & 3.2 \\
Legal Studies & 27.0 \\
Other & 9.4 \\
Total & 100.00 \\
Highest Level of Education Needed to be Successful & 58.5 \\
Undergraduate degree & 39.0 \\
Master's Degree & 2.5 \\
Other Degree & 100.00 \\
Total & \\
Typical Career Path & 13.2 \\
Start as intern & 7.5 \\
Graduate with degree in forensic accounting and join firm & 42.8 \\
Graduate with degree in accounting and start in audit department of firm & 0.6 \\
Work in legal profession before joining firm & 3.8 \\
Work in law enforcement before joining firm & 32.1 \\
Other & 100.00 \\
\hline Total & \\
\hline
\end{tabular}


Secondly, we asked the respondents some questions about "the demand for FA's in the future - next five, ten and twenty years." As can be seen from Table 12, the majority of respondents felt that the demand for FA's will increase well into the foreseeable future. In fact, ninety-four percent felt that the demand for FA's would increase in the next 10 years. Respondents were also asked if they felt that there will be enough FA's available to meet the demand in the next five, or ten years, and beyond the next 10 years. As can be seen in Table 13, many participants were unsure if the supply of FA's would be enough to meet the demand in the future.

Table12: Demand for forensic accountants

\begin{tabular}{lll}
\hline Question & Mean & \\
\hline The demand for forensic accountants in the next 5 years will: & 4.46 & $(0.646)$ \\
The demand for forensic accountants in the next 10 years will: & 4.34 \\
The demand for forensic accountants in the next 20 years will: & 4.20 & $(0.651)$ \\
\hline
\end{tabular}

Table 13: Availability of forensic accountants

\begin{tabular}{l}
\hline Question \\
Will there be enough forensic accountants available to meet the demand in the next 5 years: \\
Yes \\
No \\
Not Sure \\
Total \\
Will there be enough forensic accountants available to meet the demand in the next 10 years: \\
Yes \\
No \\
Not Sure \\
Total \\
Will there be enough forensic accountants available to meet the demand beyond the next 10 years: \\
Yes \\
No \\
Not Sure \\
Total
\end{tabular}

Finally, the respondents were asked, "In general, do FA's needs to know computer-based forensic techniques?" Eightyfour percent of the respondents answered in "yes" to this question. Moreover, we asked the respondents "how important four different software tools are for FA's: ACL, IDEA, Data Mining, and Digital Evidence Recovery." The scales were anchored at each end with the descriptors "extremely unimportant" and "extremely important," respectively. For the purpose of analysis, the descriptor "extremely unimportant" was given a weight of 1, while the descriptor "extremely important" was given a weight of 7 . The mid-point of the scale "neither" was given a weight of 4 . Table 14 shows the results. The respondents rated each of these four tools as important, with data mining being rated as the most important with a mean score of 5.83 .

Table 14: Ratings of the importance of the software tools for a forensic accountant

\begin{tabular}{lcc} 
& Table 14: Ratings of the importance of the software tools for a forensic accountant \\
\hline Tool & Mean & Standard Deviation \\
\hline ACL & 5.45 & $(1.297)$ \\
IDEA & 5.24 & $(1.232)$ \\
Data Mining & 5.83 & $(1.240)$ \\
Digital Evidence Recovery & 5.82 & $(1.224)$ \\
\hline
\end{tabular}

\section{Conclusion}

When speaking about the 'fight on terrorism', Chancellor of the Exchequer Mr. Gordon Brown, former Prime Minister of the United Kingdom stated, "What the use of fingerprints was to the 19th century, and DNA analysis was to the 20th century, so financial information and forensic accounting has come to be one of today's most powerful investigative and intelligence tools available," [51, pp. 1-33]. There is no doubt that a "qualified, trained and mature accounting professionals, possessing forensic skills, can prove to be a valuable asset to the corporate-sector, and gradually help to improve their CG system." Forensic accounting in India, of late, has come "to limelight due to the rapid increase in 'white-collar' crimes and the belief that our law-enforcement agencies do not have the 'expertise' needed or time to uncover frauds." Forensic accounting, in fact, integrates accounting, auditing, and investigative skills to conduct an examination into a company's financial statements. Broad-based knowledge is crucial to the success of entry-level FA's. The AICPA [1] conducted a survey to evaluate trends within the 'Forensic and Valuation Services' practice area. The vast majority of participating forensic accounting professionals reported "significantly increasing demand for their services in recent years. They also forecast greater demand in the next two to five years accompanied by an uptick in 
litigation and regulatory enforcement during the same period." Moreover, DeLoach [28] characterized forensic accounting as "somewhat of a 'niche' because it requires multi-disciplinary expertise that crosses the realms of accounting, criminal investigation, regulatory legislation and judicial litigation." We have seen growth in all areas of forensics, especially in computer forensics, which is being driven by the increasing use of technology and concerns about cyber-security. The FBI and Justice Departments are looking for FA's because the reach of the profession has spread to areas such as money laundering and even terrorism cases [17, pp. 12-18]. KPMG [45, 46], a large accounting firm, believe the market is sufficiently large to support an independent unit devoted strictly to 'forensic' accounting. All of the larger accounting firms, as well as, many medium-sized and boutique firms have recently created forensic accounting departments.

The recent wave of corporate fraudulent financial reporting has prompted global actions for reforms in CG and financial reporting, by governments and accounting and auditing standard-setting bodies in the U.S. and internationally. The enactment of Sarbanes-Oxley Act (SOX) of 2002 was the U.S. government's response to the wave of fraudulent corporate financial reporting experienced during the 1980s and early 2000s, and represented a significant step in regaining investors' confidence in the global financial reporting process. The Act created new and stricter statutes to avoid a repeat of previous corporate financial disasters. The arrival of the SOX, the subsequent formation of the Public Company Accounting Oversight Board [PCAOB 61], and the implementation of the Statement on Auditing Standards No. 99 [SAS 99 70] has presented the current auditing environment with a new paradigm that makes finding fraud a priority. According to Wells [73], "SAS 99 is unique because it claims that there is a risk of fraud in every business. The new standard describes specific steps that the auditors must follow during an audit engagement. These steps include pre-audit brainstorming, increased professional skepticism, additional inquiries, consideration of risk factors, a determination of the response to the risk factors, and extensive documentation." SAS 99 [70] also requires that the audit staff be evaluated to determine if they have enough fraud expertise.

In modern technology-based era, most of the criminals behind fraud use sophisticated technology and accounting tricks to commit complex frauds. This means that a FA needs the state-of-the-art facilities to uncover fraud [58, pp. 19-41]. Computers are common tools used by the culprits behind "white-collar" crimes. In order to find "the smoking gun," the FA will need to be able to dig-deep into the company's computer system. To facilitate the preservation, collection, analysis and documentation of evidence, FA's can use specialized software and computer hardware. For instance, Deloitte \& Touche has set up a world-wide network of computer forensic labs for their FA and technicians. There are many new technologies that allow the investigators to recover deleted files, crack encryptions or codes, and extract and sort data. No doubt, the accounting profession is witnessing major changes due to changes in technology. As it pertains to investigative accounting, "the modern digital environment offers new opportunities for both perpetrators and investigators of fraud. The increasing rate of computer-based financial crime has created a huge demand for the skills and services provided by FA's." Furthermore, we fully support the view point [27, pp. 379-403] that "the eXtensible Business Reporting Language (XBRL) be integrated across the accounting curriculum, in a manner relevant to the temporal stage and content of particular courses within the curriculum." Several countries have adopted XBRL in a variety of information value chains, notably in the USA context the Securities and Exchange Commission's interactive data program and in Indian context, "Corporate Filing and Dissemination System (CFDS)" used by SEBI from 2010. Thus, XBRL/CFDS has implications for the totality of the accounting curriculum and pedagogy. A program for the integration of them across a typical accounting curriculum should be developed soon [35, pp. 26-34].

The degree of professional skepticism auditors currently employ differs from the level used by FA's. This is primarily why the AICPA and education leaders have called for "more forensic accounting education for auditors" [5, pp. 345362]. In addition, the PCAOB has emphasized that the detection of fraud should be an important objective of an audit [19]. Despite the depth and breadth of authoritative standards available to guide accountant and auditor conduct, numerous stories in the press, as well as, academic research indicate that these standards have not been completely successful in eliminating ethical violations by accountants. Because of these continued breaches, confidential reporting mechanisms have received significant attention in recent years.

From the results of our analysis, we discovered that the different types of financial and economic crimes prevailing in the Indian economy include the corporate accounting frauds, security market scams, bank frauds (like ATM/credit card frauds, checks frauds, fraudulent fund transfers, withdrawals, presentation of stolen dividend warrants, and improper granting of credit facilities, inflated contract prices, embezzlement etc. The increasing demands in the current regulatory, legal, and business environments should stimulate accounting programs to emphasize and embrace forensic accounting. This research surveyed in 2011-12 120 potential practitioners, academics, and prospective users of forensic accounting services from NCR region (viz., Delhi, Gurgaon and Ghaziabad from India) as representative of the entire country to determine whether there are differences in views of the relevant skills suggested in the literature. The necessary skills required by FA's in India have been empirically examined and we have realized that financial and economic crimes have reached a level that special skills (such as those derivable from forensic accounting skills) set are required.

This study is a 'preliminary' investigation of the necessary skills, education requirements, and training requirements for FA's. We surveyed academics, practicing fraud and forensic professionals in order determine the perceptions of the 
professional community. Since little research exists in this area, present research is 'exploratory' in nature. The results indicate that "potential practitioners and academic agree that critical thinking, unstructured problem-solving, investigative flexibility, analytical proficiency, and legal knowledge are more important skills of FA's. Potential practitioners of forensic accounting services rated analysis the more important than did academic staff. However, both groups agreed with prospective users, who viewed deductive analysis as very important. The groups did not differ on oral communication, written communication, or composure rankings." These results show that "some skills are relevant and important to the outcome of forensic accounting education. Educators can use these skills as a guide to direct academic curriculum with the proper learning outcome objectives." Also, discovered are "the most important skills required by FA's to include effective written communication, auditing skills and oral communication. The least important skills include understanding the goal of a case, solve unstructured problems, and synthesize results of discovery and analysis." In correlating the important skills as identified by our respondents, it was found that critical thinking, sociology and understanding the goal of the case highly correlated to each other, likewise effective written communication, psychology, investigative ability and simplify the information. Others are effective written communication, solve unstructured problems, organizing an unstructured situation, research skills, psychology skills, simply the information and solve structured problems, amongst others. Most of the important skills have "correlations within and above 50 percent, showing that most of them have significant association with one another for FA's to function effectively."

From the test of our 'hypotheses', the results show that "core skills are not enough requirements for FA's to investigate economic and financial crimes in India." It means that some necessary skills from other disciplines, for instance behavioral sciences and law should also be embedded in the curriculum for training FA's. This result concurred with the results of other studies [75, 14]. The results of two studies [26, 33] revealed that "the skill-sets of a FA's are eclectic, these include general civilization, communication, accounting, business, auditing, technology, psychology, criminology, courtroom behavior, and meta-thinking skills, which are all critical to the effectiveness of FA's." Again, our statistical testing of the 'second' hypothesis shows that "there are significant differences in the relevant skills of FA's as given by previous researchers with the current research." This is a confirmation to the result obtained from testing the "first' hypothesis, which shows that "core skills are not enough requirements for forensic accounting practice." Most of the early researchers, who have researched in this area focused on 'core' skills of FA's. Finally, our test of hypothesis 'three' clearly states that "necessary skills of FA's, as identified by both academics and professionals, will meet employers' expectations." Employers, who include lawyers and anti-graft agencies personnel, are the users of forensic accounting services and if they concur with what accounting academics and professionals say should be the skills requirement of FA's, then academic and professional institutions should not hesitate to incorporate these skills in their curricula. Moreover, we found that all of the skills investigated in this study are 'potentially' important for FA's. The majority of the survey respondents indicated that "bachelor degree is the highest level of education necessary to be successful FA's." This may have implications for Universities when designing their curriculum. In addition, the respondents indicated that "they feel the demand for FA's will continue to be high." Universities should consider this when designing curricula and students will also find this information valuable when deciding on a major and considering career paths. Undoubtedly, much more research in this area is still needed. Universities should evaluate their course offerings and implement programs for assessment of their courses. Firm training programs should similarly evaluate course contents.

Accounting students need to be familiar with the role played by the information technology (IT) in the digital environment. In this context [59, pp. 545-559] have rightly pointed out "Knowledge and application of technology is increasingly essential in effective forensic accounting, anti-fraud programs, and fraud investigations. Accounting students need to be aware of IT-based schemes and have an appreciation for the need to use specialists to support the work of the accountant in auditing or investigating computer-based fraud and forensic accounting issues." Many higher education accounting programs are considering incorporating fraud examination and forensic accounting content in their curricula. Further research in this area could "progress to classifying skills to identified courses." The auditing environment after the passage of SOA demands students with greater understanding of risk assessment (including business and fraud risks), forensic accounting skills, the ability to understand and document controls and link controls to assertions and audit evidence, and the competence to deal with CG and other PCAOB requirements. Acquiring these skills will require changes in the basic auditing course and one/more advanced auditing courses, as well as changes in the core business and accounting curriculum.

Prior to Satyam, most companies perceived fraud as largely an internal event, primarily pinching the bottom line. They now understand that fraud can have an impact not only on the reputation and business prospects but also on the survival of the firm. This concern has led to higher demand for FA's in countries like India and China." The Ministry of Corporate Affairs in India has also established the Serious Fraud Investigation Office, which seeks the help of FA's. The government recently proposed to give more teeth to the SFIO under the new Companies Bill by providing it statutory recognition and empowering it with more powers. Particularly in this age of SOX, we require professional accountants to have curiosity and a healthy skepticism of the financial systems around them. They must be able to identify relevant facts, evaluate judgment and interpret intent; follow a clear, ethical and logical path when performing 
their work; and communicate their thoughts to peers and clients. No doubt, one must be competent in critical thinking to be effective in life, especially in a competitive business environment. Indeed, while critical thinking is necessary for accountants in today's business world, cultivating students' critical thinking skills in an accounting classroom can be a challenge. The FA's being professional members of the CG and Audit Committees, can play a far greater role in coordinating company efforts to achieve a cohesive policy of ethical behavior within an organization [11, pp. 16-42]. By helping companies to detect and prevent fraud, create a 'positive' work environment, establish 'effective' lines of communication, and be vigilant as a corporate 'watchdog', the FA's role can gradually evolve into a key component in the CG system. Let us hope that FA's, through their specialized knowledge, training and skills, will be able to improve CG scenario, still a work-in-progress, across the globe.

\section{References}

[1] American Institute of Certified Public Accountants (2011), "The 2011 Forensic and Valuation Services Trend Survey,” AICPA, available at www.aicpa.org.

[2] Aderibigbe, P. (2000), "The Role of the Forensic Chartered Accountant," The Nigeria Accountant, July, pp. 15-20.

[3] Ahadiat, N. (2010), "Skills Necessary for a Successful Career in Accounting," Journal of the Department of Accounting, College of Business Administration, California State Polytechnic University, USA.

[4] Akers, M.D. and Porter, G.L. (2003). "Your EQ Skills: Got What It Takes?” Journal of Accountancy, Vol.195, no. 3, pp. 65-69.

[5] Arens, A.A. and Elder, R.J. (2006), "Perspectives on Auditing Education after Sarbanes-Oxley”, Issues in Accounting Education, Vol. 21 No. 4, November, pp. 345-362.

[6] Association of Certified Fraud Examiners (2010, 2012), "Report to the Nations on Occupational Fraud and Abuse," ACFE. Available at www.acfe.com.

[7] Barra, R.N. (2010), “The Impact of Internal Controls and Penalties on Fraud,” Journal of information Systems, vol. 24, no. 1, pp. 1-21.

[8] Bawaneh, S.S. (2011), "Forensic Accountants in the Digital Age," Interdisciplinary Journal of Contemporary Research in Business, Vol. 3, no. 3, July, pp. 75-86.

[9] Bhasin, M.L. (2007), "Forensic Accounting: A New Paradigm for Niche Consulting," The Chartered Accountant, January, published by the ICAI, New Delhi, pp. 1000-1010.

[10] Bhasin, M.L. and Shaikh, J.M. (2012), "Corporate Governance Through an Audit Committee: An Empirical Study, International Journal of Managerial \& Financial Accounting, Vol. 4, No. 4, pp. 339-365.

[11] Bhasin, M.L. (2012), "Corporate Accounting Frauds: A Case Study of Satyam Computers Limited," International Journal of Contemporary Business Studies, Vol. 3, No. 10, pp. 16-42.

[12] Bhasin, M.L. and Shaikh, J.M., (2013), "Voluntary Corporate Governance Disclosures in the Annual Reports: An Empirical Study," International Journal of Managerial \& Financial Accounting, Vol. 5, No. 1, pp. 79-105.

[13] Bologna, G.J. and Lindquist (1995), "Fraud Auditing and Forensic Accounting: New Tools and Techniques," John Wiley \& Sons, UK.

[14] Boleigha, P. (2011), "Meaning of Forensic Accounting", A Paper Presented at the ICAN Forensic Accounting Certification Programme, March 22, Abuja.

[15] Black, W. K. 2010. "Epidemics of Control Fraud lead to Recurrent, Intensifying Bubbles and Crises," Working Paper, University of MissouriKansas City, SSRN-id 1590447.

[16] Brazel, J.F., Carpenter, T.D. and Jenkins, J.G. (2010), “Auditors' Use of Brainstorming in the Consideration of Fraud: Reports from the Field," The Accounting Review, Vol. 85, no. 4, pp. 1273-1301.

[17] Brooks, R.C., Riley, R.A. and Thomas, J. (2005), "Detecting and Preventing the Financing of Terrorist Activities: A Role for Government Accountants," The Journal of Government Financial Management, Vol. 54, issue 1, pp. 12-18.

[18] Camp, J.M. and Schnader, A.L. (2010), "Using Debate to Enhance Critical Thinking in the Accounting Classroom: the Sarbanes-Oxley Act and the US Tax Policy," Issues in accounting education, Vol. 25, no. 4, pp. 655-675.

[19] Carpenter, T.D. (2007), "Audit Team Brainstorming, Fraud Risk Identification, and Fraud Risk Assessment: Implication of SAS No. 99," Accounting Review, Vol. 82, No. 5, pp. 1119-40.

[20] Carpenter, T.D., Durtschi, C. and Gaynor, L.M. (2011), "The Incremental Benefits of a Forensic Accounting Course on Skepticism and Fraudrelated Judgments," Issues in Accounting Education, American accounting association, Vol. 26, no. 1, pp. 1-21.

[21] Chariri, A. (2009), "The Relevance of Forensic Accounting in Detecting Financial Frauds," Jurnal Organisasi dan Manajemen, vol. 3 no. 2 , pp. 81-88.

[22] Christensen, J.A., Byington, J.R. and Blalock, T.J. (2005), “Sarbanes-Oxley: Will You Need a Forensic Accountant?”, The Journal of Corporate Accounting \& Finance, March/April.

[23] Chukwunedu, O.S. and Okoye, E.I. (2011), "Forensic Accounting and Audit Expectation Gap: the Perception of Accounting Academics," available at SSRN: http://ssrn.com/abstract=1920865 or http://dx.doi.org/10.2139/ssrn.1920865.

[24] Crumbley, D.L., Heitger, L.E., and Smith, G.S. (2007), "Forensic and Investigative Accounting," Chicago: Commerce Clearing House Incorporated.

[25] COSO (2010), "Fraudulent Financial Reporting: 1987-2007," Committee of Sponsoring Organizations of the Treadway Commission, available at www.http://www.coso.org.

[26] Davis, C., Farrell, R. and Ogilby, S. (2010), "Characteristics and Skills of the Forensic Accountant," AICPA Publications.

[27] Debreceny, R. and Farewell, S. (2010), "XBRL in the Accounting Curriculum," Issues in Accounting Education, Vol. 25, no. 3, pp. 379-403.

[28] DeLoach (2012), "Forensic Accounting a Growing Niche Field," Atlanta Business Chronicle, available at www.bizjournals.com/atlanta.

[29] DeZoort, F.T., Harrison, P.D. and Schnee, E.J. (2012), "Tax Professionals Responsibility for Fraud Detection: the Effects of EngagementType and Audit Status," Accounting Horizons, Vol. 26, no. 2, pp. 289-306.

[30] Deloitte Forensic Center (2011), "Fraud, Bribery and Corruption Practices Survey," available at http://www.deloitte.com.

[31] DiGabriele, J.A. (2008), 'An Empirical Investigation of the Relevant Skills of Forensic Accountants,' Journal of Education for Business, pp. 331-338.

[32] DiGabriele, J.A. (2009), "Implications of Regulatory Prescriptions and Audit Standards on the Evolution of Forensic Accounting in the Audit Process", Journal of Applied Accounting Research, Vol. 10, Issue: 2, pp. 109 - 121. 
[33] Ekeigwe, C. (2011), "Fraud Risk Management," a paper presented at the Institute of Chartered Accountants on Nigeria Forensic Certification Training Program held on August 11-12, 2010 at Sharon Ultimate, Abuja.

[34] Ernst \& Young, (2009), "Detecting Financial Statement Fraud: What Every Manager Needs to Know," E\&Y LLP, pp.1-8. Available at www.ey.com.

[35] Efiong, E.J. (2012), "Forensic Accounting Education: An Exploration of Level of Awareness in Developing Economies," International Journal of business and management, Vol. 7, No. 4, pp. 26-34.

[36] Fortin, A. and Legault, M. (2010), "Development of Generic Competencies: Impact of a Mixed Teaching Approach on Students' Perceptions," Accounting Education: an international journal, Vol. 19, nos. 1-2, pp. 93-122.

[37] Grippo, F.J. and Ibex, T. (2003), "Introduction to Forensic Accounting," The National Public Accountant, Vol. 4, June 4-8.

[38] Groomer, S. M., and Heintz, J. (1994), “A survey of advanced auditing courses in the United States and Canada," Issues in Accounting Education, Volume 9, no.1 (spring), pp. 96-108.

[39] Transparency International (2011), "Global Corruption Report," published by Earth Scan Limited, London. Available at www.transparency.ch

[40] Golden, Thomas W., Skalak, Steven L., and Clayton, Mona M., (2011) “A Guide to Forensic Accounting Investigation,” 2nd edition, John Wiley \& Sons, New Jersey. 2011.

[41] Harris, C.K. and Brown, A.M. (2000), “The Qualities of a Forensic Accountant,” Pennsylvania CPA Journal, Vol. 71, issue 1, pp. 2-3.

[42] Hassall, T. J., Joyce, J. L., Montano, A. and Anes, J. A. D. (2005), "The Vocational Skills Gap for Management Accountants: the Stakeholders' Perspectives," Innovations in Education and Teaching International, Vol. 40, no. 1, pp.78-88.

[43] Hogan, C.E. Rezaee, Z., Riley, R.A. and Velury, U.K. (2008), "Financial Statement Fraud: Insights from the Academic Literature," Auditing: a journal of practice and theory, Vol. 27, no. 2, pp. 231-252.

[44] Jones, M. (2011), 'Creative Accounting, Fraud and International Accounting Standards,' John Wiley \& Sons, London.

[45] KPMG (2009), "The US Fraud Survey 2009”. New York, KPMG Peat Marwick Available at www.kpmginstiutes.com.

[46] KPMG (2012), "KPMG India Fraud Survey 2012," available at www.kpmginstitutes.com.

[47] Lee, D., and C. Blaszczynski (1999), "Perspectives of Fortune-500 Executives on the Competency Requirements of Accounting Graduates," Journal of Education for Business, Vol. 75, no. 2, pp. 104-107.

[48] McMullen, D.A. and Sanchez, M.H. (2010), "A Preliminary Investigation of the Necessary Skills, Education Requirements, and Training Requirements for Forensic Accountants," Journal of Forensic \& Investigative Accounting, Vol. 2, Issue 2, pp. 30-48.

[49] Messmer, M. (2004) "Exploring Options in Forensic Accounting," National Public Accountant, vol. 5(3), Dec/Jan, pp. 19-20.

[50] Murphy, P.R. and Dacin, M.T. (2011), "Psychological Pathways to Fraud: Understanding and Preventing Fraud in Organizations," Journal of business ethics, Vol. 101, issue 4, pp. 601-618.

[51] Muehlmann, B.W., Burnaby, P. and Howe, M. (2012), "The Use of Forensic Accounting Experts in Tax Cases as Identified in Court Opinions," Journal of Forensic\& Investigative Accounting, Vol. 4, Issue 2, pp. 1-33.

[52] Mampatta, S.P. and Shrivastava, N. (2010), "Companies shied away from creative accounting after Satyamgate," January 6, Money-DNA, Mumbai. Available at www.dnaindia.co.

[53] National Fraud Authority (2012), “Annual Fraud Indicator,” March. Available at www.homeoffice.gov.uk.

[54] National Crime Records Bureau (2012), "Crime in India" June.

[55] Norton's (2011), "Cybercrime Report 2011," available at www. symantec.com.

[56] O’Connell, B., Webb, L, and Schwarzbach, H.R. (2005), "Batten the Hatches! US Accounting Scandals and Lessons for Australia," Australian Accounting Review, Vol. 15, no. 2, pp. 52-67.

[57] Orumwense, J. (2013), "Implementing the Use of Auditing Skills to Identify and Avert Situations Which Could Lead to Frauds Being Perpetrated," International Journal of Finance and Accounting, Vol. 2, no. 1, pp. 19-23.

[58] Ozkul, F.U. and Pamukcu, A. (2012), "Fraud Detection and Forensic Accounting," Emerging Fraud, Springer-Verlag Berlin Heidelberg, Vol. 35, pp. 19-41.

[59] Pearson, T.A. and Singleton, T.W. (2008), "Fraud and Forensic Accounting in the Digital Environment," Issues in Accounting Education, Vol. 23, no. 4, November, pp. 545-559.

[60] PwC (2007), The 4th Biennial Global Economic Crime Survey: India", PricewaterhouseCoopers Limited. Available at www.pwc.com.

[61] Public Company Accounting Oversight Board, 2003. Available at http://www.pcaobus.org.

[62] Raj, R. (2010), "BSE’s Top 50 may be worst at Accounting," Business Today, January 21, available at www.businesstoday.intoday.in.

[63] Ramaswamy, V. (2005), “Corporate Governance and the Forensic Accountant,” The CPA Journal, vol. 75, no. 3, pp. 68-70.

[64] Robinson, S.N. and Robertson, J.C. (2012), "The Effects of Contextual and Wrongdoing Attributes on Organizational Employees' Whistleblowing Intentions Following Fraud,” Journal of business ethics, vol. 106, issue 2, March, pp. 213-227.

[65] Razaee, Z. (2002) "Forensic Accounting Practices, Education and Certification," Journal of Forensic Accounting, Vol. 3, no. 2, pp. 207-223.

[66] Razaee, Z., Crumbley, D.L. and Elmore, R.C. (2004), "Forensic Accounting Education: a Survey of Academicians and Practitioners," Advances in Accounting Education Teaching and Curriculum Innovations, Vol. 6, No 2, pp. 193-231.

[67] Rezaee, Z, Crumbley, I.D. and Elmore R.C. (2006), "Forensic Accounting Education; A survey of Academicians and Practitioners," Journal of Forensic Accounting, Vol.10, No.3, pp, 48 - 59.

[68] Rezaee, Z. and Kedia, B.L. (2012), "Role of Corporate Governance Participants in Preventing and Detecting Financial Statement Fraud," Journal of Forensic \& Investigative Accounting, Vol. 4, no. 2, pp. 176-205.

[69] Sanchez and Trewin (2004), "A Forensic Accountant as an Expert Witness in a Criminal Prosecution," Journal of Forensic Accounting, Vol. 5, Issue 1, pp. 231-235.

[70] Statement on Auditing Standards No. 99 (2002), "Consideration of Fraud in a Financial Statement Audit," Auditing Standards Board of the AICPA, October.

[71] Singleton, T.W. and Singleton, A.J. (2010), "Fraud Auditing and Forensic Accounting," 4th edition, John Wiley \& Sons Inc., New Jersey.

[72] Sugahara, S., and Coman, R. (2010), "Perceived Importance of CPA's General Skills: a Japanese Study," Asian Journal of Finance \& Accounting, Vol. 2, no. 1, pp. 1-24.

[73] Wells, J.T. (2011), "Principles of Fraud Examination," 3rd edition, John Wiley \& Sons Ltd. USA.

[74] World Trademark Review (2012), "Fighting the Crime of the 21st century," 2012, April/May, pp. 82-83. Available at www. WorldTrademarkReview.com.

[75] Zysman, A. (2008), "Forensic Accounting Demystified, World investigators network Standard Practice for investigative and forensic accounting engagement?", Canadian Institute of Chartered Accountants, Journal of Forensic Accounting. Available at ifa.alliance@cica.ca. 